\title{
QUANTIFICAÇÃO DOS PARÂMETROS MONOCÍCLICOS E CONTROLE QUÍMICO DA FERRUGEM DO PESSEGUEIRO
}

MARISE CAGNIN MARTINS

Engenheiro Agrônomo

Orientadora: Prof ${ }^{a}$. Dr ${ }^{a}$. LILIAN AMORIM

Dissertação apresentada à Escola Superior de Agricultura "Luiz de Queiroz", da Universidade de São Paulo, para obtenção do título de Mestre em Agronomia, Área de Concentração: Fitopatologia.

\author{
PIRACICABA \\ Estado de São Paulo - Brasil \\ Novembro - 1994
}


Ficha catalogratica preparada pela jeqto de livroe da Divisab de biblioteca E Decumentacto - FCla/USF

Martine, Marise Lagnir.

Guantificaço dos parametros monocicilicos e controle quimico da ferrugen do pessequeiro. Firacicata, 1994. 68p. illus.

Diss. (Mestre) - ESALQ

Bibliografia.

1. Ferrugen do péssego - Contrale quimica 2. Funga fitopatogenica - Fielacad patogeno-hospedeiro-ambiente Z. Fessego - Doenca - Manejo I. Escola superior de Agricultura Luiz de Queiroz. Firacicatáa 


\section{QUANTIFICAÇÃO DOS PARÂMETROS MONOCÍCLICOS E CONTROLE QUIMICO DA FERRUGEM DO PESSEGUEIRO}

\section{MARISE CAGNIN MARTINS}

Aprovada em: 29.11.1994

Comissão julgadora:

Prof ${ }^{a}$ Dra ${ }^{a}$ Lilian Amorim

Prof. Dr. Hiroshi Kimati

Prof. Dr. Antonio Carlos Maringoni

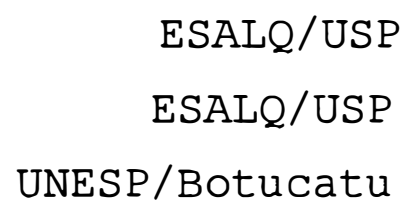

ESALQ/USP

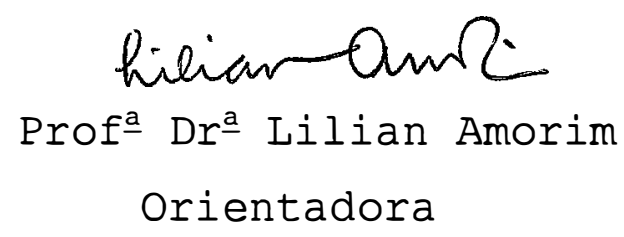


Aos meus pais, Edmilson e Maria Alice, pelo carinho e apoio constante DEDICO 


\section{AGRADECIMENTOS}

À Profa Dra ${ }^{a}$ Lilian Amorim, pelo profissionalismo, dedicação e carinho constantes.

Ao Prof. Dr. Hiroshi Kimati, consultor e amigo de todas as horas.

Ao Prof. Dr. Armando Bergamin, pela "visão clínica".

Ao Prof. Dr. Tasso Leo Krugner, pela confecção do Summary .

Ao Sr. Pedro da Silva e à Luciana Celeste Carneiro, sem os quais este trabalho não existiria.

Ao Theodorus Daamen e à Valéria Matida, pelo fornecimento das mudas de pessegueiro e pelas sugestões apresentadas.

A Cooperativa Holambra II, nas pessoas dos Engenheiros Agrônomos Antônio Bortolatto e Lourenço, pela concessão da infra-estrutura para instalação dos experimentos de campo.

As firmas de defensivos, pelo fornecimento dos produtos.

Aos amigos Larissa, Kika, Kátia, Leonel, Bel e João, pela amizade e apoio.

Aos demais colegas, professores e funcionários do Departamento de Fitopatologia da ESALQ/USP.

À CAPES, pela concessão da bolsa de estudo.

À DEUS, que apesar de ocupar o último lugar nesta lista, deixou a sua marca em cada parte dela, colocando em meu caminho, pessoas de tão alto valor. 
Página

LISTA DE FIGURAS

$\mathrm{vi}$

IISTA DE TABELAS

viii

APÊNDICE

ix

RESUMO

X

SUMMARY

xii

1. INTRODUÇÃO

01

2. REVISÃO DE IITERATURA

03

2.1. O patossistema T. discolor - P. persica .. 2.1.1. O patógeno

03

03

2.1.2. O hospedeiro

07

2.1.3. Relações patógeno - hospedeiro ....

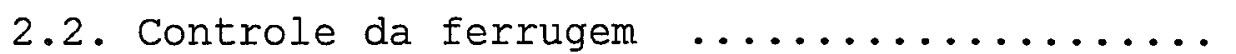

3. MATERIAI E MÉTODOS ..................

3.1. Efeito da temperatura na germinação de ure-

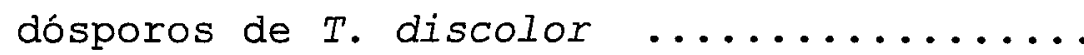

3.2. Efeito da temperatura nos parâmetros monocí clicos da ferrugem do pessegueiro .......

3.3. Controle químico da ferrugem do pessegueiro

3.3.1. Efeito de defensivos agrícolas na germinação de uredósporos de T.discolor .. 3.3.2. Eficiência de defensivos agrícolas no controle da ferrugem em plantas adultas

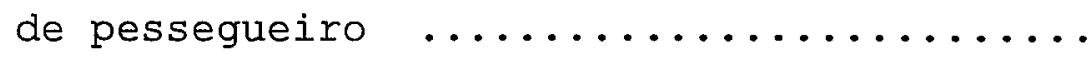
3.3.3. Efeito protetor, curativo e erradicante do inseticida cartap na ferrugem do pessegueiro

4. RESULTADOS E DISCUSSÃO

4.1. Efeito da temperatura na germinação de uredósporos de T. discolor 
4.2. Efeito da temperatura nos parâmetros monocí clicos da ferrugem do pessegueiro ...... 36

4.3. Controle químico da ferrugem do pessegueiro 4.3.1. Efeito de defensivos agrícolas na germinação de uredósporos de T.discolor .. 4.3.2. Eficiência de defensivos agrícolas no controle da ferrugem em plantas adultas de pessegueiro $\ldots \ldots \ldots \ldots \ldots \ldots \ldots \ldots$ 4.3.3. Efeito protetor, curativo e erradicante do inseticida cartap na ferrugem do pessegueiro $\ldots \ldots \ldots \ldots \ldots \ldots \ldots \ldots$

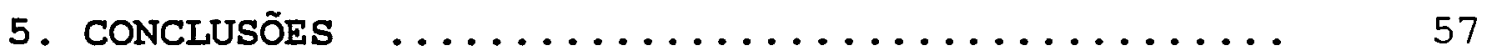

6. REFERÊNCIAS BIBLIOGRÁFICAS $\ldots \ldots \ldots \ldots \ldots \ldots \ldots$ 


\section{LISTA DE FIGURAS}

FIGURA $\mathbf{N}^{\circ}$

Página

01 Teliósporo de T. discolor (esquerda) e teliósporos de T. pruni-spinosae (direi ta)

02

Corte transversal de um aécio sobre folha de Anemone coronaria ..........

03

Aécios sobre a superfície inferior da folha de Anemone coronaria .........

04 Escala diagramática de severidade (por centagem da área foliar afetada) da fer rugem do pessegueiro $\ldots \ldots \ldots \ldots \ldots \ldots$

05 Efeito da temperatura na germinação de uredósporos de T. discolor .........

06 Curvas de progresso da ferrugem do pespessegueiro nas temperaturas de 13, 18

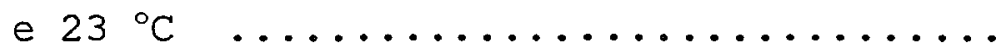

07 Frequiência de infecção da ferrugem em folhas de pessegueiro nas temperaturas de 13,18 e $23{ }^{\circ} \mathrm{C} \ldots \ldots \ldots \ldots \ldots \ldots \ldots \ldots \ldots \ldots \ldots$

08 Curvas de progresso da doença no tratamento testemunha dos cultivares Flor da

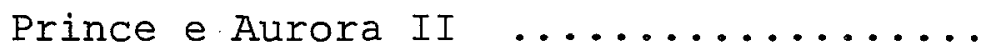

09 Efeito dos defensivos agrícolas na seve ridade da ferrugem e na desfolha do cul

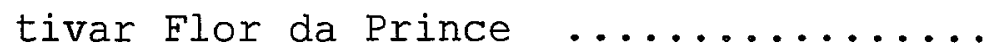


10 Vista parcial do cultivar Flor da Prince $\quad . . \ldots \ldots \ldots \ldots \ldots \ldots \ldots \ldots$.

11 Efeito dos defensivos agrícolas na seve ridade da ferrugem e na desfolha do cul var Aurora II $\ldots \ldots \ldots \ldots \ldots \ldots \ldots \ldots$

12 Curvas de progresso da ferrugem do pessegueiro em mudas pulverizadas com 0 in seticida cartap 24 horas após a inocula ção (curativo) e em mudas não tratadas

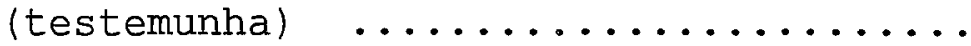

13 Efeito dos diferentes tratamentos com o inseticida cartap na ferrugem do pessegueiro $\ldots \ldots \ldots \ldots \ldots \ldots \ldots \ldots$ 


\section{LISTA DE TABELAS}

TABELA N $\mathbf{N}^{\circ}$

Página

01 Características dos defensivos agrícolas utilizados $\ldots \ldots \ldots \ldots \ldots \ldots \ldots \ldots \ldots \ldots$

02 Efeito de defensivos agrícolas na inibição da germinação (을 de uredósporos de T. discolor e $\mathrm{ED}_{50} \ldots \ldots \ldots \ldots \ldots \ldots$

03 Germinação (\%) de uredósporos de T. discolor retirados de plantas submetidas aos diferentes tratamentos com o inseticida cartap $\ldots \ldots \ldots \ldots \ldots \ldots \ldots \ldots$ 


\section{APÊNDICE}

\section{APÊNDICE $\mathrm{N}^{\circ}$}

Página

01 Curva de progresso da ferrugem do pessegueiro na temperatura de $8{ }^{\circ} \mathrm{C} \ldots \ldots$

2a Germinação de uredósporos de T. discolor em meios com defensivos agrícolas (círcu los) e ajustes das curvas aos dados ob-

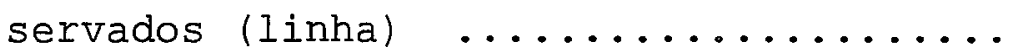

2b Germinação de uredósporos de T. discolor em meios com defensivos agrícolas (círcu los) e ajustes das curvas aos dados ob-

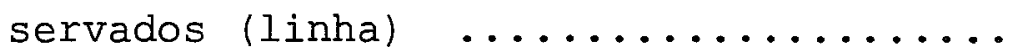

03 Dados climáticos (temperaturas mínima, média e máxima e pluviometria) obtidos na estação meteorológica de Paranapanema 


\title{
QUANTIFICAÇÃO DOS PARÂMETROS MONOCÍCLICOS E CONTROLE QUÍMICO DA FERRUGEM DO PESSEGUEIRO
}

\author{
Autora: MARISE CAGNIN MARTINS \\ Orientadora: $\mathrm{PROF}^{\mathrm{a}}$. $\mathrm{DR}^{\mathrm{a}}$. LILIAN AMORIM
}

\section{RESUMO}

A ausência de um controle eficiente da ferrugem do pessegueiro, causada por Tranzschelia discolor (Fuckel) Tranzschel \& Litivinov, é a principal causa do aumento da importância dessa doença em regiões subtropicais.

O estabelecimento de um sistema de manejo adequado da doença só será possível após o conhecimento das interações patógeno - hospedeiro - ambiente. Visando uma maior compreensão dessas relações foi avaliado o efeito da temperatura na germinação de uredósporos do fungo e nos parâmetros monocíclicos da doença. O estudo do efeito das temperaturas de $8,18,23,28$ e $36^{\circ} \mathrm{C}$ na germinação de uredósporos de T. discolor, indicou a faixa de temperatura estimada de 10 a $22^{\circ} \mathrm{C}$ como sendo a ótima para a germinação. Os parâmetros monocíclicos (frequiência de infecção e período latente) foram quantificados em mudas de pessegueiro do cultivar Flor da Prince, sob condições de câmara de crescimento, nas temperaturas de 18 e $23^{\circ} \mathrm{C}$. A temperatura de $18^{\circ} \mathrm{C}$ proporcionou uma maior freqüência de infecção e um maior período latente do que a temperatura de $23^{\circ} \mathrm{C}$.

A eficiência de onze defensivos agrícolas no controle da doença foi avaliada através de testes in vitro e in vivo. In vitro, foram determinadas a porcentagem de 
germinação de uredósporos, em meio ágar-água com defensivo nas concentrações de 1,10 e $100 \mathrm{ppm}$, e a $E D_{50}$. In vivo, a eficiência dos produtos foi avaliada em plantas adultas dos cultivares Flor da Prince e Aurora II. Os experimentos consistiram de quatro aplicações dos produtos, nas dosagens comerciais recomendadas, a intervalos quinzenais, avaliando-se a severidade da doença e a desfolha. Os produtos mancozeb, captan e tebuconazole foram os mais eficientes, tanto in vitro, como in vivo. Os produtos bitertanol e propiconazole foram semelhantes à testemunha. o efeito protetor, curativo e erradicante do inseticida cartap foi avaliado em mudas de pessegueiro do cultivar Tropical, sob temperatura de $21 \pm 4^{\circ} \mathrm{C}$. 0 tratamento protetor apresentou eficiência máxima, não ocorrendo a formação de pústulas nas folhas. Na forma curativa, o cartap reduziu sensivelmente a frequiencia de infecção e aumentou o período latente quando comparado à testemunha. O tratamento erradicante forneceu controle parcial da doença sendo observado grande número de pústulas viáveis alguns dias após a aplicação do produto. 


\section{QUANTIFICATION OF MONOCYCLIC PARAMETERS AND CHEMICAL CONTROL OF PEACH RUST}

\section{Author: MARISE CAGNIN MARTINS}

Adviser: PROF ${ }^{a}$. IILIAN AMORIM

\section{SUMMARY}

The lack of an efficient control of the peach rust caused by Tranzschelia discolor (Fuckel) Tranzschel \& Litivinov is the main cause of increase in importance of this disease in subtropical regions.

The establishment of an adequate disease management system is possible only after the knowledge of the pathogen - host - enviroment interactions. In order to get a better understanding of these relationships the effect of temperature on the germination of uredospores of $T$. discolor and the monocyclic parameters of the disease was evaluated. The optimum estimated temperature range for uredospore germination was 10 to $22^{\circ} \mathrm{C}$ in the study where the temperatures employed were $8,18,23,28$ and $36^{\circ} \mathrm{C}$. The monocyclic parameters (infection frequency and latent period) were quantified on growth chamber condition on peach plants of the cultivar flor da Prince, at the temperatures of 18 and $23^{\circ} \mathrm{C}$. The temperature of $18^{\circ} \mathrm{C}$ gave a higher infection frequency and a larger latent period then the temperature of $23^{\circ} \mathrm{C}$.

The efficiency of eleven chemical products on the control of the disease was evaluated though in vitro and in vivo tests. The percentage of uredospore germination in water - agar at the concentrations of 1,10 and 100 ppm of 
the chemicals and the $E D_{50}$ were determined. The efficiency of the products to control of peach rust, at field condition, was also evaluated in adult plants of cultivars Flor da Prince and Aurora II. The trials consisted of four applications, at the comercial dosages recomended, in a 15 days interval, the evaluation being made through the disease severity and the defoliation degree. Mancozeb, captan and tebuconazole were the most efficient, both in vitro and in vivo conditions. Bitertanol and propiconazole did not differ from control.

The protective, curative and erradicant effects of the insecticide cartap was evaluated in peach plants of the Tropical cultivar, under the temperature of $21 \pm 4^{\circ} \mathrm{C}$. The protective treatment showed maximum efficiency, with no pustule formation on the leaves. In the curative form, cartap reduced significantly the infection frequency and increased the latent period in relation to the control. The erradicant treatment gave partial control of the disease, with a great number of active pustules being observed some days after the product application. 


\section{INTRODUÇÃO}

A ferrugem do pessegueiro, causada pelo fungo Tranzschelia discolor (Fuckel) Tranzschel \& Litivinov, apesar de ser de ampla distribuição geográfica não é considerada uma doença de grande importância econômica nas regiões de clima temperado. A ausência de condições climáticas favoráveis ao desenvolvimento de alta severidade da doença e a ocorrência ao final do ciclo anual da cultura, quando as plantas já atingiram desenvolvimento suficiente para a produção da safra seguinte, são fatores que justificam a pouca importância da doença nestas áreas (ANDERSON, 1956).

Há relatos da ocorrência de epidemias de ferrugem em regiões frias, mas de um modo geral essas epidemias são esporádicas e irregulares, ocorrendo somente em anos de condições muito propícias ao desenvolvimento da doença (GOLDSWORTHY \& SMITH, 1931).

No Brasil, a cultura do pessegueiro se restringia a regiões mais frias do país, como os estados do Rio Grande do sul e Santa Catarina. Com a introdução de variedades de pessegueiro melhoradas, tolerantes ao clima subtropical, o plantio expandiu-se para áreas de clima mais ameno (MINZON, 1982). Nestas áreas de clima mais quente, das quais faz parte o estado de São Paulo, a doença passou a se tornar preocupante e estudos das relações patógeno-hospedeiro- 
ambiente tornaram-se necessários na busca de estratégias de controle.

A falta de dados quantitativos sobre o comportamento do patossistema T. discolor - Prunus persica é uma barreira na compreensão do ciclo das relações patógeno-hospedeiro. Segundo ELLISON et alii (1990) estudos das relações existentes entre os fatores ambientais e o processo de infecção do patógeno são escassos e pouco abrangentes.

Atualmente, a ferrugem do pessegueiro é uma doença de grande importância nos subtrópicos, devido às condições climáticas favoráveis e a inexistência de medidas de controle eficientes. No município de Paranapanema-SP, onde - pessegueiro é a cultura predominante, a ferrugem é a doença mais importante, causando perdas significativas na produção a cada ano (DAAMEN ${ }^{1}$ ).

Os objetivos do presente trabalho foram:

1) Avaliar o efeito da temperatura na germinação de uredósporos de $T$. discolor e nos parâmetros monocíclicos da ferrugem do pessegueiro;

2) Avaliar a eficiência de defensivos agrícolas no controle da ferrugem do pessegueiro;

3) Avaliar o efeito protetor, curativo e erradicante do inseticida cartap na ferrugem do pessegueiro.

${ }^{1}$ DAAMEN, T.A.J. (Consultoria Theodorus Anthonius Johannes, Itapetininga) Comunicação pessoal, 1993. 


\section{REVISÃO DE LITERATURA}

\subsection{O patossistema T. discolor - P. persica}

\subsubsection{O patógeno}

A ferrugem do pessegueiro é causada pelo fungo basidiomiceto Tranzschelia discolor (Fuckel) Tranzschel \& Litivinov. Sua ocorrência sobre pessegueiro foi registrada nos Estados Unidos da América entre 1880 e 1890 e na Austrália em 1890 (ANDERSON, 1956).

- fungo $T$. discolor é macrocíclico e heteróico, apresentando mais freqüentemente três tipos de esporos: aeciósporos, uredósporos e teliósporos. O estádio aecial ocorre sobre Anemone coronaria, a anêmona de jardim, e os telial e uredinial sobre espécies cultivadas de Prunus (ELLISON et alii, 1987). O estádio aecial nem sempre ocorre; aeciósporos foram observados apenas raramente na Califórnia (GOLDSWORTHY \& SMITH, 1931), registrados somente uma vez na Austrália (CARTER et alii, 1970) e não foram encontrados na África do Sul (Doidge ${ }^{2}$ citado por MITCHELI, 1975) .

${ }^{2}$ DOIDGE, E. A preliminary study of the South Africa rust fungi. Bothalia, 2:1-228, 1927. 
A ferrugem do pessegueiro apresenta usualmente apenas uredósporos. Teliósporos, quando formados, são escassos (SMITH, 1947).

A etiologia da doença já foi muito contestada no passado, sofrendo algumas alterações até receber a denominação aceita atualmente. O fungo causador da ferrugem do pessegueiro já foi considerado idêntico a Puccinia pruni-spinosae Pers. (sinonímia de Tranzschelia punctata (Pers.) Arth.), agente causal da ferrugem da ameixeira européia, sendo posteriormente separado deste gênero por diferenças em caracteres morfológicos. Os teliósporos de fungos do gênero Puccinia são formados por duas células anexadas por uma membrana comum, sendo de dificil separação, ao passo que os teliósporos no gênero Tranzschelia são constituídos por duas células distintas, facilmente separáveis (ANDERSON, 1956).

Uma outra denominação atribuída ao patógeno, e que perdurou por mais tempo, foi Tranzschelia pruni-spinosae (Pers.) Diet. Antigamente, a ferrugem, ocorrendo sobre espécies selvagens de Prunus era considerada idêntica à que ocorria sobre espécies cultivadas e ambas eram classificadas como T. pruni-spinosae. Esta nomenclatura foi utilizada até que DUNEGAN (1938), após extensivas comparações de coleções, separou esta espécie em duas "formas", T. pruni-spinosae typica, ocorrendo principalmente sobre espécies selvagens, e T. prunispinosae discolor, principalmente sobre espécies cultivadas. "Forma" typica produz o estádio aecial sobre um grande número de espécies de Ranunculaceae, enquanto que a "forma" discolor ocorre sobre Anemone coronaria. 
A separação desta espécie em duas "formas" foi feita utilizando dois critérios: combinação dos hospedeiros dos estádios aecial e telial (não foram observadas diferenças no estádio uredinial) e diferenças na morfologia dos teliósporos.

Macroscopicamente, os teliósporos sobre folhas de espécies selvagens de Prunus são pulverulentos, de cor castanho escura, enquanto os das espécies cultivadas aparecem como grupos compactos, de coloração preta (DUNEGAN, 1938). Microscopicamente, na "forma" discolor, o poro germinativo de cada uma das duas células do teliósporo localiza-se próximo ao septo entre as células, já na "forma" typica o poro germinativo na célula superior do teliósporo é apical, enquanto que na célula basal encontrase próximo ao pedicelo. Como resultado desta diferença na localização dos poros germinativos, o promicélio da "forma" discolor emerge da porção central do teliósporo e na "forma" typica emerge nas pontas do esporo (DUNEGAN \& SMITH, 1941).

Segundo SMITH (1947) as células basal e apical dos teliósporos da "forma" typica são aproximadamente do mesmo formato, tamanho e cor e são uniformemente ornamentados em toda a superfície. Na "forma" discolor a célula basal varia em forma, de globosa a irregular, e sua parede nunca é completamente ornamentada, sendo quase completamente lisa em algumas espécies (Figura 01).

Desde meados da década de 50 (ANDERSON, 1956) duas espécies de Tranzschelia são reconhecidas: T. prunispinosae é o agente causal da ferrugem que ocorre sobre espécies selvagens de Prunus e T. discolor, sobre espécies cultivadas. Segundo o mesmo autor, formas biológicas da 
espécie T. discolor têm sido demonstradas por inoculações cruzadas.


Figura 01. Teliósporo de T. discolor (esquerda) e teliósporos de T. pruni-spinosae (direita). Fonte: CUMMINS \& HIRATSUKA, 1983.

Estudos realizados por BOLKAN et alii (1985) mostram que isolados de $T$. discolor são altamente específicos, infectando somente os hospedeiros originais. Esses isolados, obtidos de diferentes espécies cultivadas de Prunus, não podem ser separados pelas características morfológicas e sim pela patogenicidade, sendo portanto sugerido pelos autores o uso de formae speciales para separar os isolados de $T$. discolor como: $T$. discolor $f . s p$. dulcis para isolados que atacam amendoeiras, T. discolor $f$. sp. persicae para os que ocorrem sobre pessegueiro e $T$. discolor $f$. sp. domesticae para ameixeira européia. A informação sobre parasitismo especializado de $T$. discolor é muito útil em programas de manejo da doença. 
KABLE et alii (1986), através de inoculações cruzadas, reforçaram estudos anteriores e comprovaram existir especialização fisiológica do fungo na Austrália. Quando uredósporos de $T$. discolor de pessegueiro e ameixeira foram inoculados reciprocamente, infecções ocorreram, embora com maior período latente e menor frequiência de infecção. Estas diferenças devem limitar o desenvolvimento epidêmico de uma "raça" particular de ferrugem sobre um hospedeiro diferente do seu habitual, entretanto a capacidade de infectar mais do que uma espécie de Prunus tem valor na sobrevivência do fungo no inverno.

\subsubsection{O hospedeiro}

A ferrugem é de distribuição geográfica generalizada, ocorrendo onde espécies de Prunus são cultivadas comercialmente. Segundo SMITH (1947) a doença já foi detectada na Europa, Ásia (China, Índia e Japão), África (Egito e Uganda), Oceania (Austrália e Nova Zelândia), América do Sul (Brasil, Colômbia, Uruguai e Venezuela), América Central e América do Norte (México e Estados Unidos da América).

Segundo KABLE et alii (1986), hospedeiros comuns do fungo $T$. discolor são plantas de pêssego e nectarina (Prunus persica I. Batsch), damasco ( $P$. armeniaca L.), amêndoas ( $P$. dulcis (Mill.) Webb), ameixa européia ( $P$. domestica L.) e ameixa japonesa ( $P$. salicina Lindl.). Ocasionalmente, ocorre sobre cerejas (P. avium L.) (BOLKAN et alii, 1985).

A cultura do pessegueiro, alvo de estudo neste trabalho, tem destacada expressão no contexto mundial, uma 
vez que sua fruta, além de ser saborosa e apresentar aspecto atraente, é de ótimo valor nutritivo, podendo ser consumida tanto in natura como industrializada (BARBOSA et alii, 1990).

o pessegueiro, tipicamente de clima temperado, até pouco tempo era cultivado somente em áreas com altitudes acima de 600 metros, mas hoje em dia, como resultado de melhoramento genético, já existem variedades adaptadas para clima mais quente (MINZON, 1982). Nas regiões de clima subtropical, onde as plantas permanecem aproximadamente nove meses enfolhadas, a doença ferrugem passou a ser problema (DAAMEN ${ }^{1}$ ).

A intensidade dos sintomas da ferrugem varia de acordo com o hospedeiro e o estádio fenológico da cultura (ANDERSON, 1956). O fungo $T$. discolor é primariamente um patógeno foliar, podendo infectar, no caso do pessegueiro, também frutos e ramos (Laundow \& Rainbow ${ }^{3}$ citados por ELLISON et alii, 1987).

GOLDSWORTHY \& SMITH (1931) forneceram uma descrição bem detalhada dos sintomas da doença causada por $T$. discolor sobre o pessegueiro. Segundo estes autores, as folhas nunca são completamente cobertas pelas lesões de ferrugem, que se distribuem irregularmente sobre toda a superficie oụ se aglomeram em algumas porções da folha. Inicialmente, observam-se manchas angulares, verdeamareladas em ambas as superfícies da folha que, com o avanço da doença, adquirem uma coloração amarela brilhante na superfície superior. $\mathrm{Na}$ superfície inferior há a

\footnotetext{
${ }^{3}$ LAUNDOW, G. F. \& RAINBOW, A.F. Tranzschelia pruni-spinosae var. discolor. CMI. Descriptions of pathogenic fungi and bacteria $n^{\circ} 287,1971$.
} 
formação de pústulas recobertas por uredósporos de coloração marrom.

Nas folhas afetadas, o primeiro indício de um distúrbio fisiológico é a destruição dos cloroplastos, evidenciada pela mudança de coloração das lesões. Após a frutificação do fungo, as lesões tornam-se mais espessas do que o tecido sadio adjacente, devido à presença de micélio fúngico intercelular e também de uma camada estromática de tecido pseudoparenquimatoso. o micélio fúngico é constituído de hifas polinucleadas de diâmetro relativamente reduzido, nunca ultrapassando 8 micrômetros de espessura. A camada estromática em folhas e ramos é formada diretamente abaixo da epiderme e, no fruto, a várias distâncias dessa camada. No estroma, há a formação de cordões miceliais criando uma estrutura compacta, no ápice da qual os uredósporos se originam.

Em períodos de alta temperatura, as porções centrais das lesões podem secar, formando áreas mortas. O fungo continua, entretanto, a sobrevivência nas margens desses tecidos mortos.

Em casos de alta severidade da doença, que ocorre principalmente no final da safra, abcisão foliar resultando em uma desfolha parcial ou quase completa da planta pode ser observada.

Nas regiões subtropicais, a queda precoce das folhas pode provocar uma segunda floração no outono, com prejuízos consideráveis à planta, uma vez que essa florada não será aproveitada e a planta gasta muita energia para emiti-la, além do armazenamento de nutrientes já estar comprometido pela ausência das folhas, órgãos de reserva (BLEICHER \& TANAKA, 1982). 
A desfolha debilita a planta com consequientes reflexos em produções futuras, como diminuição da produtividade e da vida útil do pomar (EMPRESA BRASILEIRA DE PESQUISA AGROPECUÁRIA - EMBRAPA, 1990). De acordo com TEVIOTDALE et alii (1994) a desfolha precoce pode ocasionar prejuizos superiores a $30 \%$ na produtividade, a longo prazo, em árvores de ameixeira européia.

No que diz respeito ao fruto, este é raramente afetado, sendo que a infecção somente ocorre quando predominam condições ótimas para a germinação do fungo e o fruto está em avançado estádio de maturidade fisiológica (GOLDSWORTHY \& SMITH, 1931).

Os frutos atacados apresentam manchas arredondadas, deprimidas, de coloração esverdeada, as quais podem ser recobertas por pústulas de ferrugem. Em alguns casos, o fungo produz apenas soros internos que nunca se rompem sobre a camada superficial do fruto (ANDERSON, 1956). No início, as células afetadas não mostram mudanças características, mas plasmólise é notada com o avanço da doença. Segundo MINZON (1982) a área atacada pode apresentar rachaduras.

Infecções nos ramos têm sido raramente observadas sobre pessegueiro, mas são registradas como bastante comuns sobre ameixeira na Austrália e Nova Zelândia. No início da primavera, micélio dormente do fungo, proveniente de infecção no final do outono de anos anteriores formam uredósporos que rompem através da casca sem formar lesões definidas. Depois, com o crescimento do ramo, essas áreas infectadas abrem fendas longitudinais que na maioria dos casos cicatrizam, mas em alguns casos o micélio do fungo permanece ativo para originar novas pústulas no ano seguinte (ANDERSON, 1956). 


\subsubsection{Relações patógeno-hospedeiro}

o estudo das relações patógeno-hospedeiro constitui a base para aplicação de medidas de controle de uma doença. De acordo com ANDERSON (1956), infecções primárias de T. discolor sobre espécies de Prunus são resultantes de aeciósporos ou uredósporos.

No primeiro caso, aécios pequenos em forma de xícara, preenchidos com esporos dispostos em cadeia, são formados sobre Anemone coronaria. São distribuidos uniformemente sobre as folhas, sendo facilmente identificados pelas margens brancas expandidas e pelos esporos marrons escuros (Figuras 02 e 03). O micélio é perene nesses tecidos e continua a produzir aécios até a morte do hospedeiro. Aeciósporos, atingindo uma folha de Prunus spp., germinam e após a colonização do tecido do hospedeiro produzem uredósporos, responsáveis pela infecção secundária (CUNNINGHAM, 1922).

A infecção primária, originada por uredósporos que sobreviveram no inverno, é a que ocorre em nossas condições. Segundo BLEICHER \& TANAKA (1982) e PENTEADO (1983) a infecção do pessegueiro ocorre no início da primavera, através da produção de uredósporos nas pústulas dos cancros dos ramos. Os uredósporos têm longevidade de 45 a 50 dias (podendo sobreviver por um período máximo de 150 dias).

A infecção secundária, em ambos os casos, ocorre após a disseminação de uredósporos, que são facilmente carregados por correntes aéreas. A disseminação de uredósporos pode ser realizada também por outros agentes, como por exemplo insetos (CUNNINGHAM, 1922) e chuva (BLEICHER \& TANAKA, 1982). Ocasionalmente, após a maturação 
dos uredósporos há a formação dos teliósporos que ao atingir o hospedeiro alternativo ( $A$. coronaria) produzem os basidiósporos, estruturas responsáveis pela infecção. Pícnias e aécios são formados em seguida. Os aeciósporos maduros são disseminados pelo vento até as plantas de Prunus spp., assim completando o ciclo.

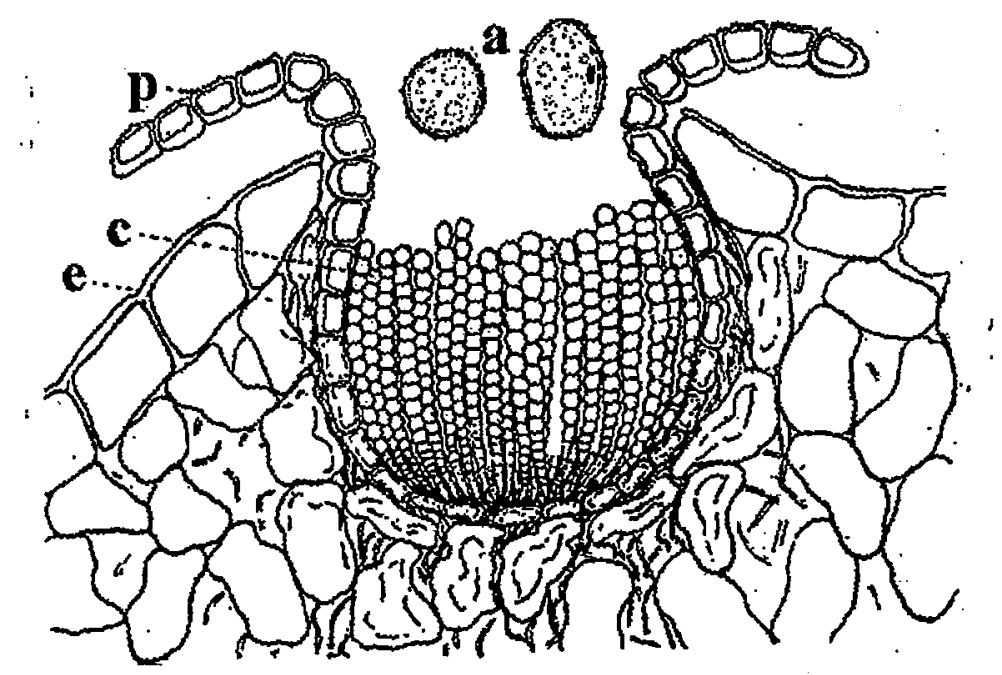

Figura 02. Corte transversal de um aécio sobre folha de Anemone coronaria. $\mathbf{a}=$ aeciósporos; $\mathbf{p}=$ parede do aécio; $\mathbf{c}=$ cadeia de aeciósporos; $\mathbf{e}=$ epiderme (CUNNINGHAM, 1922).

Em regiões mais quentes, a presença de hospedeiro alternativo não é essencial ao ciclo de vida do patógeno, visto que a sobrevivência dos uredósporos é facilitada pelas temperaturas mais amenas. Em áreas frias, os uredósporos apresentam dificuldade na sobrevivência. 0 hospedeiro alternativo, nem sempre está presente na proximidade das plantas cultivadas. Deste modo, com a redução ou ausência de inóculo inicial, as chances de ocorrência de infecção são grandemente reduzidas, o que 
explica a menor severidade da doença nessas áreas (ANDERSON, 1956).



Figura 03. Aécios sobre a superfície inferior da folha de Anemone coronaria (CUNNINGHAM, 1922).

A forma de sobrevivência do inóculo no inverno, periodo de repouso vegetativo da planta, discutida por SMITH (1947), ainda não está totalmente esclarecida. A sobrevivência sobre Anemone coronaria é considerada apenas de importância regional, uma vez que este hospedeiro nem sempre ocorre nas áreas de cultivo de Prunus spp. Segundo TEVIOTDALE et alii (1994), Anemone coronaria não é de ocorrência comum na Califórnia, ao contrário da Europa, onde é aparentemente de importância considerável na sobrevivência de $T$. discolor no período dormente da planta. Segundo GOLDSWORTHY \& SMITH (1931), $\bigcirc$ fungo $T$. discolor sobrevive na forma de micélio dormente em cancros dos ramos de pessegueiro infectados no outono, 0 qual originará uredósporos na primavera seguinte. Este modo de 
sobrevivência nunca foi observado em ameixeira francesa devido ao fato do patógeno, nesta cultura, infectar exclusivamente as folhas (ELLISON et alii, 1987).

A sobrevivência do fungo na forma de uredósporos é a mais aceita. De acordo com ELLISON et alii (1987) uredósporos podem sobreviver em folhas de ameixeira infectadas, caídas no solo ou localizadas no interior da copa das árvores. Apesar da viabilidade dos uredósporos diminuir com 0 tempo há sempre uma proporção capaz de germinar na primavera. Uredósporos sobre folhas remanescentes do outono, presas nas árvores, sobrevivem melhor do que sobre folhas caídas no solo.

Com relação às condições climáticas favoráveis à infecção, há uma afirmação generalizada de que os períodos quentes e úmidos, freqüentes nas áreas subtropicais nos meses de setembro a abril, são os mais propícios. A infecção primária ocorre na primavera e há um rápido aumento da doença no final do verão e começo do outono.

Conforme GOLDSWORTHY \& SMITH (1931), os uredósporos de T. discolor germinam em ampla faixa de temperatura, sendo $8^{\circ} \mathrm{C}$ e $38^{\circ} \mathrm{C}$ os limites mínimo e máximo para germinação, respectivamente, com o ótimo situando-se entre 13 e $26^{\circ} \mathrm{C}$. $\mathrm{Na}$ faixa de temperatura de 22 a $24^{\circ} \mathrm{C}$, o tubo germinativo mostra crescimento máximo, abaixo de $14^{\circ} \mathrm{C}$ e acima de $26^{\circ} \mathrm{C}$ os tubos germinativos são injuriados. Temperaturas elevadas provocam ramificação da hifa ou rompimento das extremidades dos tubos germinativos logo após a germinação, enquanto em temperaturas baixas o rompimento das pontas não ocorre, mas a ramificação é muito comum.

DUNEGAN \& SMITH (1941) encontraram a faixa de temperatura de 10 a $25^{\circ} \mathrm{C}$ como sendo a mais favorável ao crescimento do tubo germinativo sobre meio ágar-água, 
avaliado após um período de incubação de 3 horas. Houve somente alguns poucos esporos iniciando a germinação a $30^{\circ} \mathrm{C}$ e nenhum germinou a $35.5^{\circ} \mathrm{C}$. Segundo os autores, a faixa de temperatura de 20 a $23^{\circ} \mathrm{C}$, ótima para germinação, é provavelmente similar àquela para crescimento do tubo germinativo. ELLISON et alii (1988) verificaram que a temperatura é o principal fator que afeta a viabilidade do uredósporo, sendo que as temperaturas de 25 a $30^{\circ} \mathrm{C}$ são bem criticas.

ELLISON et alii (1990), ao contrário de autores anteriores, avaliaram o efeito da temperatura na germinação de uredósporos de $T$. discolor utilizando períodos de incubação variáveis. Demonstraram que a germinação ocorre mais rapidamente entre 13 e $26^{\circ} \mathrm{C}$, sendo que indices de germinação igual ou superior a $80 \%$ foram obtidos dentro de uma hora e meia de incubação. Com temperaturas acima de $28^{\circ} \mathrm{C}$ e abaixo de $8^{\circ} \mathrm{C}$ a germinação não ultrapassa $80 \%$ em três horas.

o crescimento do tubo germinativo diferiu da germinação em sua resposta à temperatura. No caso do crescimento do tubo germinativo, foi obtida uma faixa de temperatura ótima mais estreita de 17 a $22^{\circ} \mathrm{C}$, comparada com a de 13 a $26^{\circ} \mathrm{C}$ para germinação.

Dados sobre o efeito da luz no processo de infecção de T. discolor são bem raros. Estudos pioneiros desenvolvidos por ELLISON et alii (1992) demonstraram que tanto a germinação como o crescimento do tubo germinativo deste patógeno foram sensíveis à luz.

A luz retarda a germinação, sendo que seu efeito deletério aumenta à medida que se eleva a intensidade Iuminosa. Quando a temperatura declina abaixo de $20^{\circ} \mathrm{C}$, 0 efeito torna-se mais pronunciado. Entretanto, a germinação 
máxima não é afetada por qualquer combinação intensidade luminosa-temperatura e níveis de germinação da ordem de $90 \%$ são registrados dentro de 24 horas para todas as combinações testadas.

A luz reduziu o crescimento do tubo germinativo e, à semelhança da germinação, seu efeito aumentou com o aumento da intensidade luminosa.

Apesar dos trabalhos anteriores terem se preocupado com as condições de ambiente favoráveis ao fungo, nenhum deles, até a atualidade, estudou as condições favoráveis ao progresso da doença, seja sob ambiente controlado, seja em condições de campo; portanto a quantificação dos parâmetros monocíclicos da doença faz-se necessária para este fim.

Os parâmetros monocíclicos mais utilizados em estudos epidemiológicos, segundo PARLEVLIET (1979), são: período de incubação, período latente, freqüência de infecção e esporulação.

- período de incubação é o período de tempo compreendido entre a inoculação e 0 aparecimento dos sintomas;

- período latente é o período de tempo entre a inoculação e a produção de esporos;

- Ireqüência de infecção é $\bigcirc$ número de lesões produzidas por unidade de área, a partir de uma concentração conhecida de inóculo.

- esporulação é o número de esporos produzidos por unidade de área de tecido afetado e/ou por unidade de tempo.

Quanto maiores os períodos de incubação e latente e quanto menor a freqüência de infecção, menor será o número de ciclos do patógeno sobre seu hospedeiro. Conseqüentemente, menor a severidade final de doença. 
Assim, determinando-se 0 efeito do ambiente sobre os parâmetros monocíclicos do patossistema, pode-se inferir sobre as condições ambientais favoráveis ao desenvolvimento de epidemias.

KABLE et alii (1986), em ensaio de inoculação artificial de $T$. discolor sobre pessegueiro, encontraram (em condições de casa de vegetação) 10 a 12 dias como sendo - período de incubação e 13 dias como o período latente. Estes valores foram determinados para a variedade Elberta em condições de temperatura de 15 a $25^{\circ} \mathrm{C}$. Sabe-se, no entanto, que estes valores são muito influenciados pela genética da interação patógeno-hospedeiro e pela temperatura de incubação das plantas.

\subsection{Controle da ferrugem}

A inexistência de controle eficiente da ferrugem do pessegueiro é uma das principais causas do aumento considerável da importância da doença em regiões subtropicais $\left(\right.$ DAAMEN $\left.^{1}\right)$.

A aplicação de fungicidas é a forma de controle mais utilizada, uma vez que não existem cultivares comerciais resistentes à doença (BLEICHER \& TANAKA, 1982) e as poucas práticas de natureza cultural recomendadas, tais como a queima ou a incorporação no solo de folhas e ramos infectados (HUTTON, 1950), podem ser utilizadas apenas como medidas de controle auxiliares. O uso isolado dessas medidas culturais além de não conseguir deter o rápido progresso da doença esbarra no problema da inviabilidade econômica.

o controle químico, apesar de ser a medida mais usada, se mostra deficiente, já que há pouquíssimos 
fungicidas registrados para a cultura, sendo que esses produtos além de não serem registrados para o controle da ferrugem especificamente, nem sempre fornecem controle satisfatório.

De uma maneira geral, as recomendações de controle químico existentes são pré-estabelecidas, não levando em consideração a influência das condições ambientais sobre o ciclo das relações patógeno-hospedeiro. Segundo ELIISON et alii (1990), este programa rotineiro de controle pode resultar em tratamento excessivo em anos secos, com consequiente desperdício de produto e trabalho, ao passo que em épocas úmidas pode proporcionar um controle inadequado.

Antigamente, os produtos cúpricos e os sulfurados eram os mais utilizados no controle da ferrugem do pessegueiro, sendo que os sulfurados eram os mais tóxicos ao fungo (GOLDSWORTHY \& SMITH, 1931).

Segundo CUNNINGHAM (1922), o esquema de controle químico da ferrugem do pessegueiro incluía cinco pulverizações: a primeira quando as gemas floriferas começavam a inchar, a segunda um mês após a queda das pétalas, a terceira quando os frutos atingissem metade do seu tamanho normal, a quarta um pouco antes da maturação dos frutos e a quinta logo após a colheita. Os produtos utilizados eram a calda bordalesa ou a calda sulfocálcica diluída (1:120) na primeira pulverização e apenas a calda sulfocálcica diluída nas demais. GOLDSWORTHY \& SMITH (1931) também verificaram a eficiência dos compostos sulfurados no controle da ferrugem do pessegueiro.

De acordo com BLEICHER \& TANAKA (1982), quatro pulverizações no verão, espaçadas durante quinze dias, com mancozeb, maneb, thiram e zineb são suficientes para o controle da ferrugem do pessegueiro. Segundo os autores, 
pulverizações outonais ou tratamentos de inverno podem ser realizados visando a diminuição do inóculo inicial. PENTEADO (1983) também recomenda quatro pulverizações no verão, com os mesmos produtos mais propineb.

MICHAILIDES \& OGAWA (1986), testando o efeito do enxofre molhável e mancozeb no controle da ferrugem da ameixeira francesa, verificaram que mancozeb foi o mais eficiente, sendo que apenas uma única aplicação em meados do verão é necessária quando a doença não está presente na área e duas pulverizações quando a doença já existe. In vitro, a germinação de uredósporos sobre meio batatadextrose-ágar acidificado acrescido de 5, 10 ou $15 \mu \mathrm{g}$ ia/ml de enxofre molhável ou mancozeb, foi reduzida em 11, 33 e $38 \%$, com enxofre molhável, respectivamente, e $97 \%$ nas três concentrações de mancozeb.

KABLE et alii (1987b), estudando o controle da ferrugem da ameixeira francesa, sob condições de inoculação natural, constataram que os ditiocarbamatos mancozeb e zineb, o último com ou sem a adição de espalhante adesivo, deram controle superior ao dithianon, captafol ou triforine. Estudos adicionais envolvendo inoculação artificial reforçaram este resultado, com uma única pulverização de mancozeb e zineb fornecendo aproximadamente 12 a 13 semanas de proteção. Nestes estudos, chlorothalonil e bitertanol também foram superiores ao dithianon e captafol, mas pareceram ser menos persistentes do que os ditiocarbamatos. Propiconazole e myclobutanil foram relativamente ineficientes como protetores. Segundo os autores, a ocorrência de chuva dentro de um ou dois dias após a pulverização reduz a eficácia e a persistência dos fungicidas, mas quando ocorre alguns dias ou semanas depois, tem pouco efeito. 
Conforme KABLE et alii (1987a), os produtos propiconazole e myclobutanil, em doses relativamente baixas, apresentam alto efeito curativo sobre $T$. discolor em folhas de ameixeira francesa. Os fungicidas apresentam um maior impacto sobre o patógeno se aplicados no início do período latente, quando eles completamente inibem 0 desenvolvimento da lesão, ou mesmo após o aparecimento dos sintomas quando suprimem a esporulação, atuando neste último caso como erradicante.

Em seu trabalho anterior, KABLE et alii (1987b) constataram a baixa atividade protetora dos produtos propiconazole e myclobutanil, neste (KABLE et alii, 1987a), verificaram a alta atividade curativa destes produtos. Segundo os autores, este impasse entre atividade protetora e curativa pode talvez ser explicado pelo fato dos produtos apresentarem máxima atividade em um período de tempo, após aplicação, relativamente curto. Talvez os fungicidas, após serem absorvidos pelos tecidos da planta, sejam desdobrados em compostos com atividade fungitóxica baixa dentro de minutos ou horas após a aplicação. Outra hipótese que explicaria os resultados encontrados seria a baixa atividade daqueles produtos contra uredósporos não germinados. No manejo da doença, devem ser aliados estes produtos com ação curativa com aqueles com ação protetora, como o mancozeb e zineb.

Agricultores na Austrália têm controlado a ferrugem da ameixeira francesa através de aplicações mensais de fungicidas protetores entre meados de outubro e dezembro, sendo que em épocas úmidas as aplicações devem ser estendidas até meados de março ou abril. Este programa de pulverização é baseado na experiência a longo prazo do 
produtor, mas não existem dados experimentais que validem ou não este manejo dos fungicidas (ELLISON et alii, 1990).

No sul do Brasil, de acordo com recomendações da EMBRAPA (1990), apenas duas pulverizações de mancozeb, uma antes e outra após a colheita, são suficientes para o controle da ferrugem do pessegueiro.

$\mathrm{Na}$ região de Paranapanema-SP $\circ$ esquema de pulverização da ferrugem do pessegueiro consiste em pulverizações quinzenais dos fungicidas captan e mancozeb de agosto até meados de setembro. A partir de setembro até final de novembro, os agricultores fazem aplicações de produtos sistêmicos como o tebuconazole, a cada quinze dias, intercalando pulverizações com os fungicidas protetores em épocas chuvosas. De dezembro até final de janeiro recomendam-se pulverizações semanais de captan e mancozeb e de fevereiro até abril utilizam o tebuconazole quinzenalmente (DAAMEN ${ }^{1}$ ) .

TEVIOTDALE et alii (1994) constataram a superioridade do fungicida mancozeb sobre enxofre no controle da ferrugem da ameixeira francesa, aplicado duas ou três vezes no verão.

Do exposto observa-se que trabalhos referentes ao controle químico da ferrugem de Prunus spp., especialmente no Brasil, são escassos, assim como o número de produtos testados é bem pequeno. Estudos englobando uma maior gama de produtos é de suma importância no controle da doença.

As ferrugens de outras culturas vêm sendo controladas, de maneira eficiente, com 0 uso de diversos fungicidas sistêmicos como por exemplo triadimefon, triadimenol, fenarimol, bitertanol e propiconazole, entre outros. Estes fungicidas inibidores da biossintese do ergosterol, maior e mais importante grupo de compostos 
sistêmicos, alteram a morfologia da célula, causando modelos de crescimento anormais, como hifas mais grossas e/ou com ramificação excessiva. Esse grupo de substâncias não exerce efeitos imediatos sobre a respiração ou síntese de macromoléculas, eles causam acúmulo de ácidos graxos livres e esteróis intermediários (SIEGEL, 1981). Geralmente não atuam sobre a germinação, apesar de em algumas espécies de fungos isso ocorrer (TRINCI \& RYLEY, 1983).

FREITAS et alii (1994) avaliaram o efeito dos produtos propiconazole, myclobutanil, cyproconazole, bitertanol mais chlorothalonil e triadimenol no controle da ferrugem branca do crisântemo (Dendranthema morifolium) e observaram que os produtos myclobutanil seguido do propiconazole foram os mais eficientes. Produtos utilizados no controle da ferrugem de outras culturas devem ser testados no controle da ferrugem do pessegueiro.

Recentemente, ITO (1993) relatou o inseticida cartap como erradicante do fungo Uromyces appendiculatus, agente causal da ferrugem do feijoeiro. Esta forma de controle é muito vantajosa em sistemas de manejo integrado. Neste caso, pode-se aguardar que a severidade da doença atinja um certo limiar de dano econômico, para então proceder-se ao controle com a aplicação do produto específico.

Em uma tentativa preliminar de determinar a ação do cartap sobre uredósporos de T. discolor, sobre pessegueiro, (KIMATI ${ }^{4}$ ) verificou um efeito erradicante sobre pústulas maduras em folhas. Após a aplicação do cartap as pústulas modificaram sua coloração, tornando-se esbranquiçadas.

\footnotetext{
${ }^{4}$ KIMATI, H. (Escola Superior de Agricultura "Luiz de Queiroz" USP- Piracicaba) Comunicação pessoal, 1993.
} 


\section{MATERIAL E MÉTODOS}

\subsection{Efeito da temperatura na germinação de uredósporos de T. discolor}

Uredósporos de $T$. discolor, mantidos e multiplicados em mudas de pessegueiro do cultivar flor da Prince a $18^{\circ} \mathrm{C}$, foram suspensos em água destilada com Tween 80 (0.02\%) e padronizados com hemacitômetro na concentração de $9,3 \times 10^{4}$ uredósporos/ml. Uma alíquota de $0.1 \mathrm{ml}$ dessa suspensão foi distribuída, com auxílio de uma alça de Drigalski, por placa de Petri contendo meio ágar-água.

As placas de Petri foram mantidas em câmaras de crescimento de plantas, marca Conviron, nas temperaturas de $8,18,23$ e $28^{\circ} \mathrm{C} \pm 0.5^{\circ} \mathrm{C}$, sob escuro, durante 48 horas. Após esse periodo, foram depositadas três gotas de lactofenol por placa e efetuou-se a avaliação da porcentagem de germinação de uredósporos sob microscópio óptico comum.

Durante a avaliação, dividiu-se a superfície inferior das placas em quatro quadrantes para facilitar a contagem, uma vez que os quadrantes lidos eram marcados, evitando-se assim contar o mesmo esporo mais de uma vez. Foram contados os 100 primeiros esporos encontrados por placa, sob a objetiva de $10 \mathrm{x}$. Eram considerados germinados os esporos que apresentavam tubo germinativo de comprimento igual ou maior ao comprimento do esporo. 
- delineamento experimental utilizado foi o inteiramente casualizado com três repetições, sendo que cada placa constituía uma repetição.

Testou-se a temperatura de $36^{\circ} \mathrm{C}$ em ensaio conduzido separadamente com a mesma metodologia descrita anteriormente. A câmara de incubação utilizada forneceu variação de $\pm 3^{\circ} \mathrm{C}$ e o período de incubação foi de 24 horas.

A análise da curva de germinação dos uredósporos de T. discolor em função da temperatura foi feita utilizando o modelo não linear Beta generalizado (HAU \& KRANZ, 1990), cuja função é $Y=B_{3} \times\left(T-B_{4}\right)^{B_{1}} \times\left(B_{5}-T\right)^{B_{2}}$, onde: $Y=$ porcentagem de germinação, $B_{4}$ e $B_{5}=$ estimativas das temperaturas minima e máxima do processo infeccioso. Neste experimento foram fixados os valores de 0 e $32^{\circ} \mathrm{C}$ para os parâmetros $B_{4}$ e $B_{5}$, respectivamente, estimativas baseadas em observações prévias.

A porcentagem de germinação estimada pela função Beta generalizada foi obtida através de regressão não linear realizada com o programa de computador BMDP (DIXON, 1985), que estima, por interações, os valores dos parâmetros $B_{1}, B_{2}$ e $B_{3}$. Segundo HAU \& KRANZ (1990) esse modelo foi muito útil na avaliação do efeito da temperatura sobre vários processos do ciclo de vida do agente causal do oídio da cevada.

3.2. Efeito da temperatura nos parâmetros monocíclicos da ferrugem do pessegueiro

Neste experimento, foram utilizadas mudas de pessegueiro, de aproximadamente um ano e meio de idade, do cultivar Flor da Prince. As mudas, provenientes de 
Itapetininga-SP, foram transplantadas para sacos plásticos contendo uma mistura de esterco de curral, areia e solo argiloso na proporção de 1,5: 1,0:3,0, respectivamente, em número de uma por vaso.

Uredósporos do fungo $T$. discolor foram coletados em pessegueiros, naturalmente infectados, em um campo experimental do Departamento de Horticultura da ESALQ USP, sendo que a viabilidade dos uredósporos sobre meio ágar-água foi previamente determinada. Foi preparada uma suspensão desses esporos em água destilada com Tween 80 (0.02\%) na concentração de $1 \times 10^{5}$ uredósporos $/ \mathrm{ml}$.

As mudas foram inoculadas por aspersão da suspensão de esporos nas superfícies inferior e superior de todas as folhas da planta, até o ponto de escorrimento superficial. Após a inoculação, as plantas foram cobertas com sacos plásticos transparentes umedecidos, para se formar una câmara úmida, e mantidas nas temperaturas de 13,18 e $23^{\circ} \mathrm{C}$ $\pm 0.5^{\circ} \mathrm{C}$, sob escuro, por 48 horas. Após esse periodo, a câmara úmida foi retirada e as plantas permaneceram nas respectivas temperaturas sob fotoperíodo de 12 horas.

A avaliação consistiu de contagens diárias do número de pústulas maduras, sendo que essas contagens iniciaram-se quando do aparecimento das primeiras e estenderam-se até a estabilização no número de pústulas formadas. Foram avaliadas todas as folhas dos ramos marcados, que eram em número de três por planta.

o comprimento e a maior largura das folhas foram medidos na primeira e na última avaliação, visando a determinação da área foliar. o procedimento utilizado para a estimativa da área foliar do pessegueiro foi feito em ensaio conduzido separadamente em plantas sadias. Cinqüenta e uma folhas de tamanhos diversos da variedade Flor da 
Prince foram coletadas e tiveram sua área foliar medida, três vezes cada, com planímetro. Cada folha, identificada através de um número seqüencial, teve seu comprimento e sua maior largura determinados. A correlação entre área foliar e comprimento e/ou largura foi determinada por regressões lineares utilizando-se como variável independente o valor real da área (média de três leituras) e como variável dependente a largura, o comprimento ou a combinação de ambos. A escolha do melhor modelo de regressão baseou-se nos valores do coeficiente de determinação, sendo que 0 modelo escolhido foi o de In(comprimento) $x$ (largura).

os parâmetros monocíclicos avaliados foram o período latente e a frequiência de infecção. O tempo entre a inoculação e $\circ$ aparecimento de $50 \%$ dessas pústulas foi considerado como o período latente. A freqüência de infecção foi considerada como o número máximo de pústulas esporulantes por $\mathrm{cm}^{2}$ de área foliar.

A análise dos dados foi feita através de equações de regressões não lineares com 0 modelo de Gompertz $\left(Y=B_{1} \times \exp \left(-B_{2} \times \exp \left(-B_{3} \times X\right)\right)\right.$, onde $Y=$ frequiência de infecção,

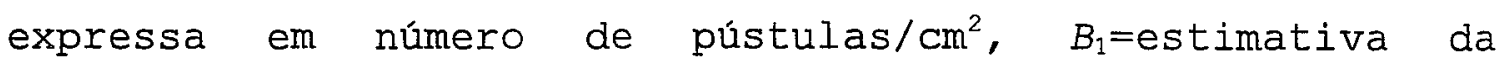
assintota máxima, $B_{2}$ =parâmetro relacionado ao inóculo inicial e $B_{3}=$ taxa aparente de infecção), utilizando-se o programa PlotIt (EISENSMITH, 1985).

Um segundo experimento foi instalado de maneira semelhante testando-se as temperaturas de 8,18 e $28^{\circ} \mathrm{C} \pm$ $0.5^{\circ} \mathrm{C}$. A concentração da suspensão utilizada na inoculação foi de $5 \times 10^{4}$ uredósporos $/ \mathrm{ml}$. Essa concentração foi determinada, utilizando-se valores de germinação previamente obtidos sobre meio ágar-água, de modo que o 
número total de esporos germinados fosse igual ao do primeiro teste.

\subsection{Controle químico da ferrugem do pessegueiro}

\subsubsection{Efeito de defensivos agrícolas na germinação de uredósporos de $T$. discolor}

Uredósporos de T. discolor, obtidos de mudas de pessegueiro do cultivar Flor da Prince mantidas em câmaras de crescimento na temperatura de $18^{\circ} \mathrm{C}$, foram suspensos em água destilada com Tween 80 (0.02\%) na concentração de $1 \mathrm{X}$ $10^{5}$ uredósporos/ml. Uma alíquota de $0.1 \mathrm{ml}$ dessa suspensão foi distribuida, com uma alça de Drigalski, sobre meio ágar-água contendo um defensivo agrícola. Cada produto utilizado foi avaliado nas concentrações de 1,10 e 100 ppm de ingrediente ativo.

Os defensivos agrícolas testados foram bitertanol, captan, cartap, cyproconazole, flutriafol, mancozeb, myclobutanil, propiconazole, tebuconazole nas formulações concentrado emulsionável e pó molhável e triadimenol. o plaqueamento de uredósporos sobre meio de cultura ágar-água sem defensivos funcionou como testemunha.

As placas permaneceram em germinadores a $18^{\circ} \mathrm{C} \pm 0.5^{\circ} \mathrm{C}$, no escuro por 72 horas. Decorrido esse tempo, foram depositadas três gotas de lactofenol por placa e a avaliação da porcentagem de germinação dos uredósporos foi realizada sob microscópio óptico comum, utilizando-se a objetiva de $10 \mathrm{x}$.

o delineamento experimental utilizado foi 0 constituído de 34 tratamentos, com três repetições cada. 
Os dados foram avaliados por análise de variância e as médias comparadas pelo teste de Tukey, a 5\% de probabilidade. A ED $\mathrm{D}_{50}$ (dose eficiente para inibir 50\% da germinação) foi calculada através da utilização de regressões não lineares obtidas com $\circ$ modelo exponencial ( $Y=B_{1} \times \exp \left(B_{2} \times X\right)$, onde $Y=$ porcentagem de germinação de uredósporos; $B_{1}$ =assintota máxima, expressa em porcentagem de germinação e $B_{2}$ =taxa de progresso da curva), com 0 auxílio do programa de computador PlotIt.

\subsubsection{Eficiência de defensivos agrícolas no controle da ferrugem em plantas adultas de pessegueiro}

o experimento foi conduzido em duas propriedades localizadas no município de Paranapanema-SP, uma com pessegueiros do cultivar Flor da Prince e outra, do cultivar Aurora II, ambos com cerca de três ano e meio de idade.

Para o cultivar Flor da Prince, foram utilizadas quatro linhas de cultivo da cultura. As duas linhas das extremidades, que foram deixadas como bordadura, não receberam tratamento, servindo como fonte de inóculo. Nas duas linhas centrais foram distribuidos os tratamentos, sendo que cinco plantas foram tratadas e três deixadas sem tratar e assim sucessivamente. Essas três árvores não tratadas, além de funcionarem como fonte de inóculo, foram deixadas para evitar a deriva dos produtos durante a aplicação, diminuindo assim riscos de interferência entre as parcelas.

No caso do cultivar Aurora II, foram utilizadas três linhas de cultivo, as duas externas como bordadura e a 
central com os tratamentos. Nessa área foram deixadas duas plantas não tratadas entre quatro tratadas.

Cada planta funcionou como uma repetição, sendo que para o cultivar Flor da Prince o número de repetições foi cinco e para o cultivar Aurora II, quatro.

Uma breve descrição dos defensivos agrícolas testados encontra-se na Tabela 01.

Tabela 01. Caracteristicas dos defensivos agrícolas utilizados.

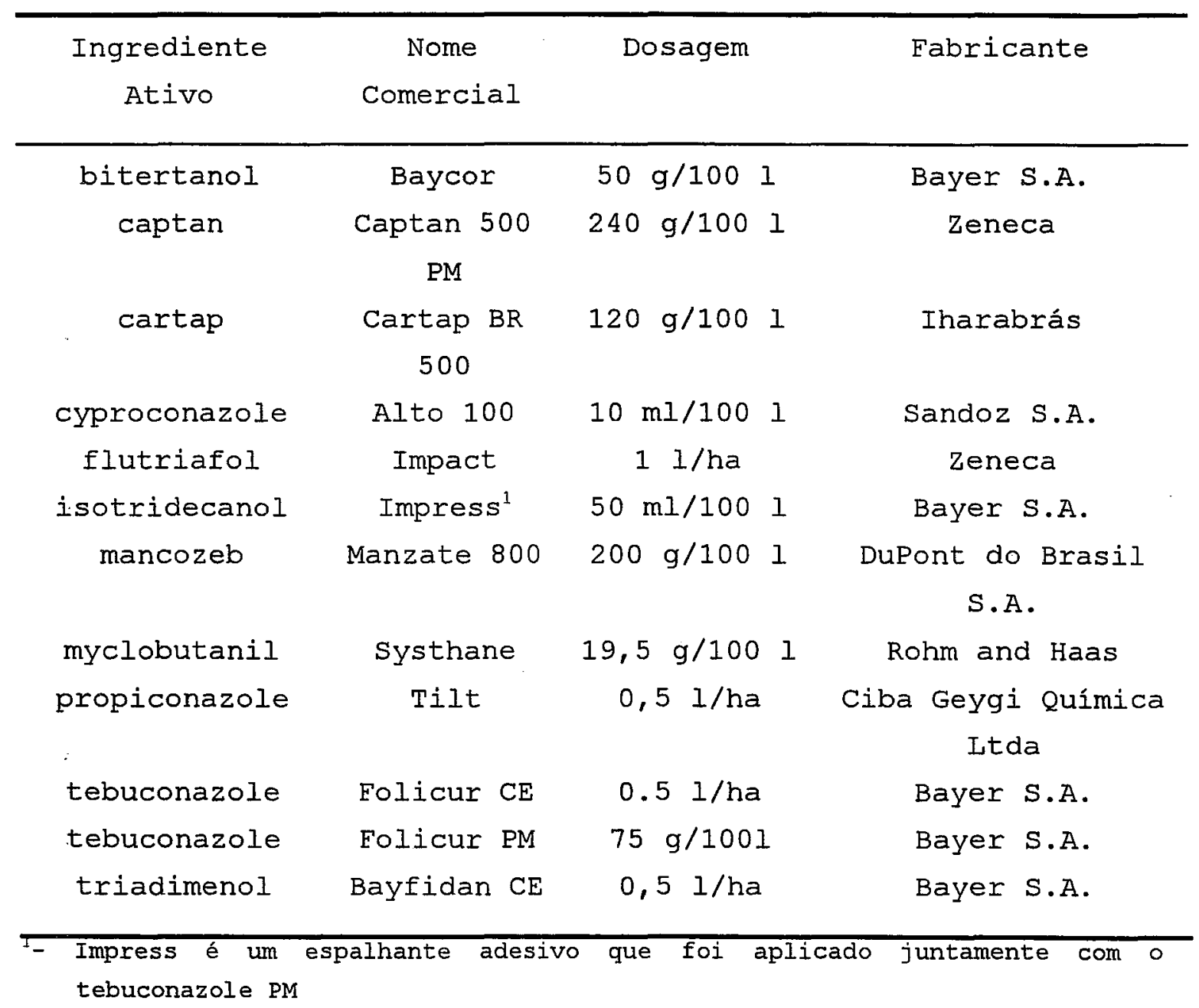


As aplicações dos defensivos agrícolas, a cada 15 dias, foram realizadas com pulverizador Jacto costal motorizado, com capacidade de 13 litros. O volume de calda aplicado por árvore foi de 2.6 litros. Foram feitas cinco pulverizações no cultivar Flor da Prince e quatro no Aurora II. Essa pulverização adicional no cultivar flor da Prince foi feita somente para captan e mancozeb, produtos protetores, aplicados entre a segunda e a terceira aplicação devido ao período chuvoso.

A instalação do experimento na propriedade com Flor da Prince foi feita em 17 de novembro de 1993 e na área com Aurora II em 06 de dezembro de 1993.

A eficiência dos produtos foi avaliada através da severidade da doença e do índice de desfolha. A avaliação foi feita em ramos marcados nos quatro quadrantes da árvore.

A avaliação da severidade da doença, realizada antes da primeira pulverização e quinze dias após a última, foi feita através do uso de uma escala diagramática. Esta escala diagramática foi elaborada seguindo-se as recomendações de JAMES (1974) quanto à lei de WeberFechner, segundo a qual a vista humana responde a estímulos que crescem em escala logarítmica, e quanto aos limites inferior e superior, que devem estar dentro dos limites observados em condições naturais de infecção. Deste modo, a escala elaborada neste trabalho, com 10 níveis de severidade teve como limites inferior e superior $0.063 \mathrm{e}$ $7,0 \%$ de área doente, respectivamente (Figura 04). Os níveis intermediários foram calculados segundo o modelo logístico (HORSFALL \& BARRAT, 1945). A distribuição das pústulas na lâmina foliar e os limites de severidade foram determinados 
conforme amostra de folhas com sintomas coletados de campo experimental.

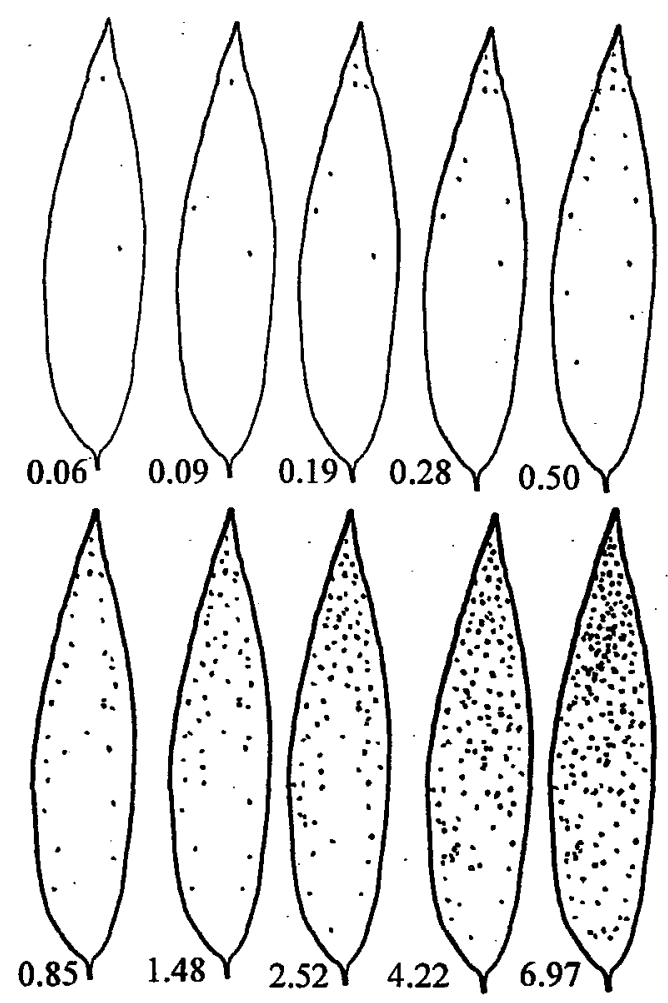

Figura 04. Escala diagramática de severidade (porcentagem da área foliar afetada) da ferrugem do pessegueiro.

A testemunha foi avaliada cinco vezes, nas datas de pulverizações e 15 dias após a última aplicação, para determinação do progresso da doença durante o período total do ensaio.

A desfolha foi computada através da diferença entre o número de folhas obtido na primeira e na última avaliação. Os dados foram avaliados por análise de variância e as médias dos tratamentos comparadas pelo teste de Tukey, a 5\% de probabilidade. 
Dados meteorológicos foram obtidos durante o período de condução do ensaio.

\subsubsection{Efeito protetor, curativo e erradicante do inseticida cartap na ferrugem do pessegueiro}

Neste experimento foram utilizadas mudas de pessegueiro com um ano e meio de idade do cultivar Tropical, plantadas individualmente em sacos plásticos contendo a mistura de esterco de curral, areia e solo argiloso na proporção de 1,5: 1,0:3,0, respectivamente.

Uma suspensão de esporos, coletados em mudas de pessegueiro do cultivar Flor da Prince mantidas a $18^{\circ} \mathrm{C}$, foi preparada em água destilada com Tween $80(0,02 \%)$ na concentração de $6,0 \times 10^{4}$ uredósporos $/ \mathrm{ml}$.

A inoculação das mudas foi feita por aspersão de 40 ml da suspensão de esporos em ambas as faces de todas as folhas de cada planta, até $\circ$ ponto de escorrimento superficial. A câmara úmida foi feita através da cobertura das plantas com sacos plásticos umedecidos. As mudas inoculadas permaneceram por 48 horas no escuro em uma sala de incubação com temperatura de $21^{\circ} \mathrm{C} \pm 4^{\circ} \mathrm{C}$. Após esse período, retirou-se a câmara úmida, fornecendo-se um fotoperíodo de 12 horas.

Foram aplicados $40 \mathrm{ml}$ da solução de cartap por planta, em tratamento protetor, curativo e erradicante, conforme dosagem recomendada pelo fabricante. No tratamento preventivo $\circ$ inseticida foi aplicado 24 horas antes da inoculação das mudas; no tratamento curativo, 24 horas após a inoculação e no tratamento erradicante a aplicação foi feita quando da existência de pústulas formadas (26 dias 
após a inoculação). Plantas inoculadas que não receberam pulverizações de cartap funcionaram como testemunha.

A avaliação do efeito protetor, curativo e erradicante do inseticida cartap sobre a ferrugem do pessegueiro foi feita através de contagens diárias do número de pústulas formadas, até a estabilização desse número. O comprimento e a maior largura das folhas foram medidos na primeira e na última avaliação, para determinação da área foliar. Foram avaliadas todas as folhas dos ramos marcados, em número de três por planta.

Foram determinados o período latente e a freqüência de infecção, sendo os dados analisados através de equações de regressões.

- delineamento utilizado foi o inteiramente casualizado com três repetições.

Uredósporos coletados dos diversos tratamentos foram plaqueados sobre meio ágar-água, sendo que a concentração da suspensão de esporos utilizada foi de $1 \times 10^{5}$ uredósporos/ml. A avaliação da porcentagem de germinação de uredósporos foi feita após 48 horas de incubação a $18^{\circ} \mathrm{C}$, sob escuro.

o delineamento utilizado foi o inteiramente casualizado com cinco repetições. 


\section{RESULTADOS E DISCUSSÃO}

\subsection{Efeito da temperatura na germinação de uredósporos de T. discolor}

- efeito da temperatura na germinação de uredósporos de $T$. discolor foi estimado pela curva de ajuste obtida com uma generalização da função Beta $\left(Y=\left(T^{0.959} \times(32-T)^{1.048} \times 0.361\right.\right.$, com $Y=$ =porcentagem de germinação e $T$ =temperatura). Os resultados originais e o ajuste obtido estão representados na Figura 05.

A germinação máxima estimada ( $>80 \%$ ) ocorreu na faixa de temperatura de 10 a $22^{\circ} \mathrm{C}$. Temperaturas inferiores à ótima estimada foram menos prejudiciais à germinação do que temperaturas mais elevadas, observando-se aproximadamente $75 \circ$ de germinação dos esporos a $8^{\circ} \mathrm{C}$ e apenas $350^{\circ}$ a $28^{\circ} \mathrm{C}$.

$\grave{A}$ medida que se elevou a temperatura houve uma sensível redução na germinação dos uredósporos. Com cerca de $36^{\circ} \mathrm{C}$ a germinação foi completamente nula, motivo pelo qual os resultados desta temperatura não foram plotados no gráfico.

A faixa de temperatura ótima para a germinação, de 10 a $22^{\circ} \mathrm{C}$, obtida neste experimento, foi inferior aos valores de 13 a $26^{\circ} \mathrm{C}$ obtidos por GOLDSWORTHY \& SMITH (1931) e ELLISON et alii (1990). No entanto o limite inferior ótimo para a germinação, de $10^{\circ} \mathrm{C}$, foi o mesmo encontrado por 
DUNEGAN \& SMITH (1941), para crescimento do tubo germinativo.

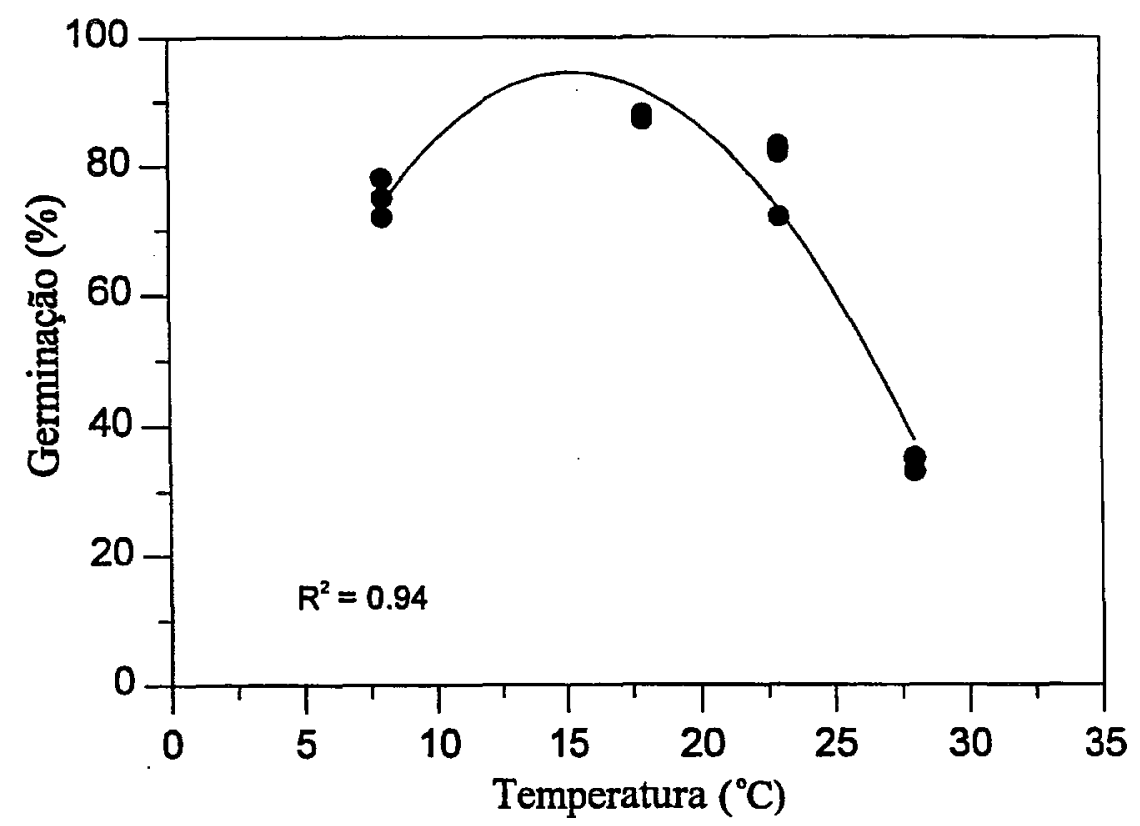

Figura 05. Efeito da temperatura na germinação de uredósporos de T. discolor.

- fato de T. discolor ser um patógeno que evoluiu em coexistência com o hospedeiro em clima temperado, pode explicar o porquê de temperaturas abaixo da faixa considerada ótima serem menos deletérias ao processo do que temperaturas acima dessa faixa; há uma maior tolerância do patógeno a temperaturas mais amenas.

GOLDSWORTHY \& SMITH (1931) citaram a temperatura de $8^{\circ} \mathrm{C}$ como sendo $\circ$ limite inferior para a germinação de uredósporos de T. discolor. No presente experimento, a porcentagem de germinação in vitro, nesta temperatura, foi alta. In vivo, houve o desenvolvimento da doença (resultados discutidos no próximo item), o que faz supor 
que o limite inferior para a germinação é bem abaixo de $8^{\circ} \mathrm{C}$.

No que se refere à temperatura máxima para a germinação, pode-se concluir que seu valor situa-se acima de 30 e abaixo de $36^{\circ} \mathrm{C}$. A ausência de germinação a $36^{\circ} \mathrm{C}$ obtida no presente estudo foi similar aos resultados de DUNEGAN \& SMITH (1941) que observaram apenas alguns esporos iniciando a germinação a $30^{\circ} \mathrm{C}$ e nenhum germinando a $35.5^{\circ} \mathrm{C}$.

\subsection{Efeito da temperatura nos parâmetros monocíclicos da ferrugem do pessegueiro}

Os resultados do efeito da temperatura nos parâmetros monocíclicos da ferrugem do pessegueiro, obtidos no primeiro experimento, encontram-se nas Figuras 06 e 07.

As curvas estimadas de progresso da doença, obtidas pelo ajuste dos dados ao modelo de Gompertz, foram: $Y=3.23 \times \exp (-311.39 \times \exp (-0.13 \times X))$, para $18^{\circ} \mathrm{C} \quad \mathrm{e}$ $Y=1.58 \times \exp (-102.37 \times \exp (-0.12 \times X))$, para $23^{\circ} \mathrm{C}, \quad$ onde $Y=$ pústulas $/ \mathrm{cm}^{2}$ e $X=$ horas após a inoculação. Com estes resultados (Figura 06) pode-se verificar que tanto a freqüência de infecção $\left(B_{1}=3.23 \pm 0.29\right.$, para $18^{\circ} \mathrm{C}$ e $B_{1}=1.58$ \pm 0.12 , para $23^{\circ} \mathrm{C}$ ) como o período latente ( $\mathrm{L}=463$ para $18^{\circ} \mathrm{C}$ e 403 para $23^{\circ} \mathrm{C}$ ) foram significativamente maiores na temperatura de $18^{\circ} \mathrm{C}$ do que na de $23^{\circ} \mathrm{C}$, através do teste $t$. Para a temperatura de $13^{\circ} \mathrm{C}$ não foi possivel ajustar um modelo de regressão porque a coleta dos dados foi interrompida antes de ser atingido o ponto de inflexão da curva. Com os dados existentes, qualquer modelo se ajustaria à curva. A interrupção na coleta dos dados ocorreu devido a grande oscilação térmica apresentada pela 

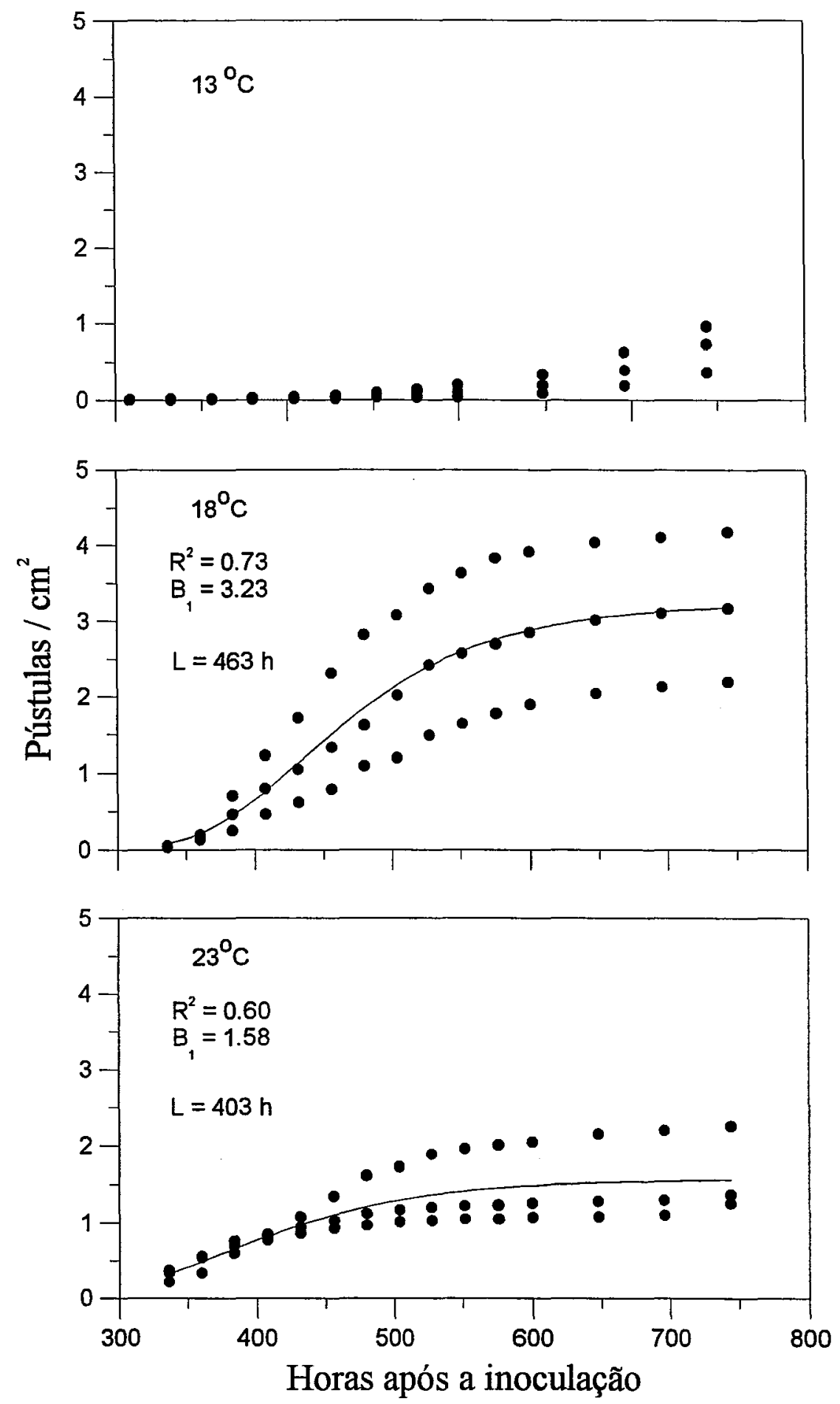

Figura 06. Curvas de progresso da ferrugem do pessegueiro nas temperaturas de 13,18 e $23^{\circ} \mathrm{C}$.

$\mathrm{R}^{2}=$ coeficiente de determinação do ajuste

$\mathrm{B}$ = assintota máxima (pústulas $/ \mathrm{cm}^{2}$ )

$\mathrm{L}^{1}=$ periodo latente (horas) 
Câmara de crescimento, resultante de um blecaute mecânico, impossibilitando assim a confiabilidade nos dados que seriam obtidos após a ocorrência desse problema.

A Figura 07 ilustra os resultados apresentados, mostrando a maior freqüência de infecção em folha de pessegueiro a $18^{\circ} \mathrm{C}$ do que a $23^{\circ} \mathrm{C}$. Na temperatura de $13^{\circ} \mathrm{C}$, além da freqüência de infecção ser menor, o tamanho das pústulas também era mais reduzido.
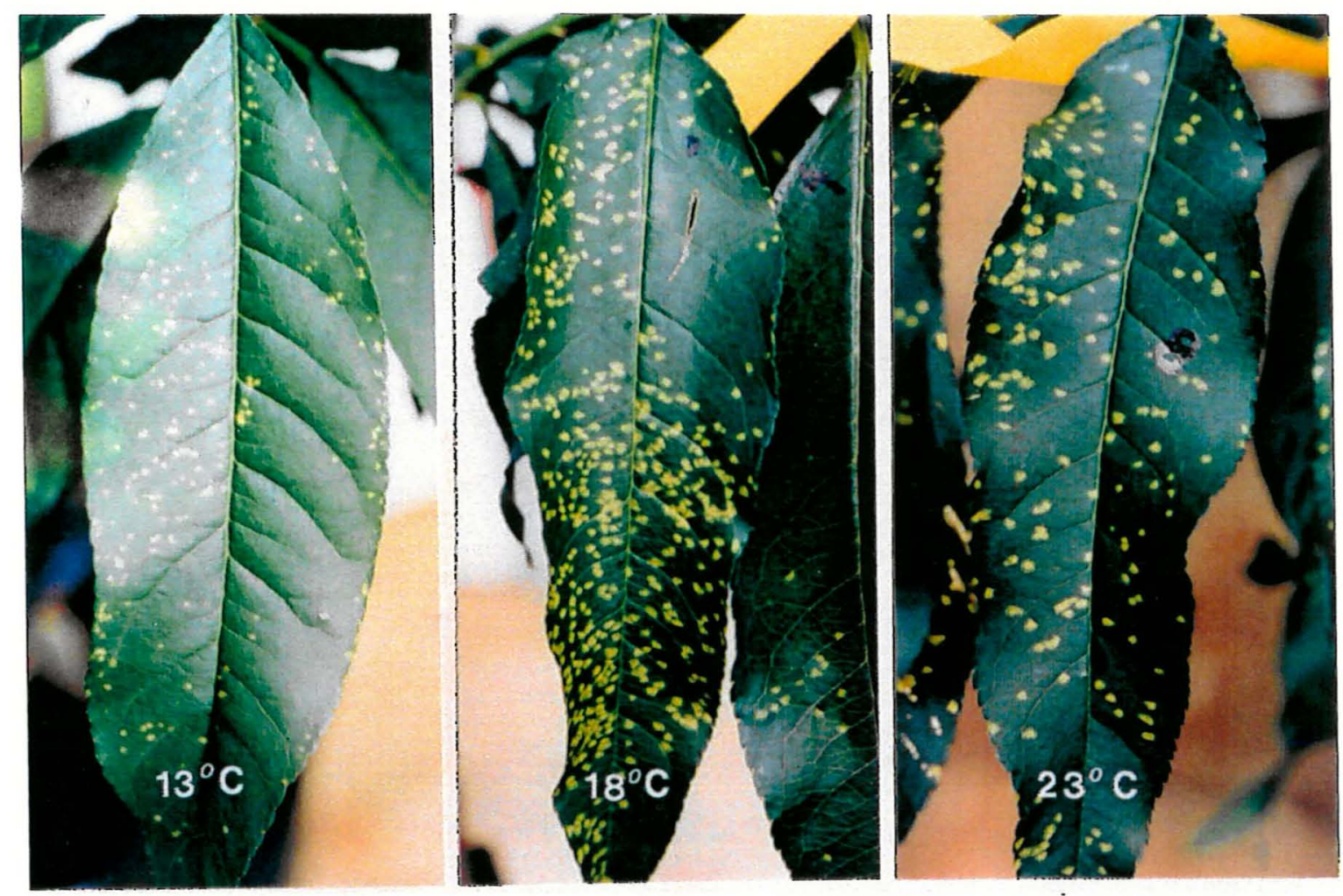

Figura 07. Freqüência de infecção da ferrugem em folhas de pessegueiro nas temperaturas de 13,18 e $23^{\circ} \mathrm{C}$.

Os resultados obtidos em câmaras de crescimento refletiram o que é observado em condições naturais de campo, onde temperaturas mais amenas propiciam uma maior severidade da doença. 
A maior freqüência de infecção e o maior período latente observados a $18^{\circ} \mathrm{C}$, quando comparados com a temperatura de $23^{\circ} \mathrm{C}$, mostraram que a temperatura de $18^{\circ} \mathrm{C}$ favorece a infecção e a temperatura de $23^{\circ} \mathrm{C}$, a colonização. Do exposto pode-se inferir que uma alternância da temperatura diurna/noturna próxima à faixa favorável $\left(23 / 18^{\circ} \mathrm{C}\right)$ seria ideal para o desenvolvimento do ciclo das relações patógeno-hospedeiro-ambiente.

A maior freqüência de infecção a $18^{\circ} \mathrm{C}$ coincide com a maior taxa de germinação dos uredósporos ocorrida nessa temperatura, observada no experimento anterior.

o periodo latente obtido com as temperaturas de 18 e $23^{\circ} \mathrm{C}$ (19 e 17 dias, respectivamente) foi um pouco superior ao de 13 dias encontrado por KABLE et alii (1986). Essa diferença resulta das diferentes condições utilizadas por aqueles autores que trabalharam com outro cultivar (Elberta), com temperaturas variáveis de 15 a $25^{\circ} \mathrm{C}$, além da variação de outros fatores. O período latente da ferrugem do pessegueiro, mostra-se superior ao das ferrugens de outras culturas. Para culturas anuais, como o feijoeiro (BACCHI, 1993) e trigo (MEHTA \& ZADOKS, 1970), períodos latentes menores de 10 dias têm sido relatados na literatura. A longa duração da latência não impede, no entanto, o rápido desenvolvimento de epidemias no campo, sua taxa aparente de infecção (discutida no item 4.3.2) compensa este efeito.

No segundo experimento, a temperatura de incubação constante de $8^{\circ} \mathrm{C}$ foi muito drástica às plantas, ocasionando, inicialmente, uma descoloração nas folhas com subsequiente queda. Os resultados obtidos estão contidos no Apêndice 01. A freqüência de infecção, que permaneceu relativamente estabilizada $\left(<0.05\right.$ pústulas $\left./ \mathrm{cm}^{2}\right)$ até mais ou 
menos 900 horas após a inoculação, cresceu abruptamente após esse período (Apêndice 01), devido provavelmente, à desfolha precoce que, reduzindo $\circ$ número de folhas por ramo, quase todas contendo algumas pústulas, elevou a frequiência de infecção média por planta.

- Os primeiros sintomas a $8^{\circ} \mathrm{C}$, foram observados 400 horas após a inoculação, período este suficiente para o aparecimento de 50 응 das pústulas em outras temperaturas (Eigura 06). Em condições naturais, a temperatura nunca é constante, por isso, seria oportuno avaliar o efeito de temperaturas um pouco mais altas, como por exemplo $10^{\circ} \mathrm{C}$, ou alternar a de $8^{\circ} \mathrm{C}$ com outras mais elevadas, para quantificar o efeito de temperaturas mais baixas.

A curva de progresso da doença a $18^{\circ} \mathrm{C}$ apresentou comportamento semelhante à obtida com a mesma temperatura no primeiro experimento. Com $28^{\circ} \mathrm{C}$ houve ataque severo de ácaros acarretando intensa desfolha, o que impediu a continuidade na avaliação.

De uma maneira geral, estudos nessas áreas são ainda bem incipientes e muito tem de ser feito. A determinação do efeito do ambiente sobre os parâmetros monocíclicos da ferrugem do pessegueiro é de suma importância no conhecimento das condições ambientais favoráveis ao desenvolvimento de epidemias dessa doença.

\subsection{Controle químico da ferrugem do pessegueiro}

\subsubsection{Efeito de defensivos agrícolas na germinação de uredósporos de T. discolor}

$\mathrm{Na}$ Tabela 02 estão contidos os resultados do efeito de defensivos agrícolas na germinação de uredósporos de $T$. 
discolor, expressos em porcentagem de inibição da germinação em relação à testemunha e $\mathrm{ED}_{50}$.

Tabela 02. Efeito de defensivos agrícolas na inibição da germinação $\left(\frac{\circ}{0}\right)^{1}$ de uredósporos de $T$. discolor e $\mathrm{ED}_{50}$.

\begin{tabular}{lrrrr}
\hline & \multicolumn{3}{c}{ concentração do } & produto (ppm) \\
\cline { 2 - 4 } Tratamentos & 1 & 10 & 100 & ED $_{50}$ \\
\hline bitertanol & 4.82 & $28.26 \mathrm{~cd}$ & $39.31 \mathrm{C}$ & $>100$ \\
captan & 22.06 & $100.00 \mathrm{a}$ & $100.00 \mathrm{a}$ & $<10$ \\
cartap & 0 & $0 \mathrm{f}$ & $86.90 \mathrm{~b}$ & $>10$ \\
cyproconazole & 0 & $25.51 \mathrm{def}$ & $89.65 \mathrm{~b}$ & $>10$ \\
flutriafol & 75.85 & $88.97 \mathrm{~b}$ & $100.00 \mathrm{a}$ & $<$ \\
mancozeb & 91.72 & $100.00 \mathrm{a}$ & $100.00 \mathrm{a}$ & $<1$ \\
myclobutanil & 0 & $26.90 \mathrm{cde}$ & $100.00 \mathrm{a}$ & $>10$ \\
propiconazole & 4.82 & $13.78 \mathrm{def}$ & $100.00 \mathrm{a}$ & $>10$ \\
tebuconazole CE & 96.54 & $100.00 \mathrm{a}$ & $100.00 \mathrm{a}$ & $<1$ \\
tebuconazole PM & 3.46 & $51.73 \mathrm{c}$ & $100.00 \mathrm{a}$ & $>10$ \\
triadimenol & 58.62 & $97.25 \mathrm{ab}$ & $100.00 \mathrm{a}$ & $<1$ \\
\hline \multicolumn{1}{c}{ CV (8) } & & 11.2 & 21.64 & 1 \\
\hline
\end{tabular}

1 Médias originais. Os dados foram transformados em arco seno da raiz $\mathrm{x} / 100$ para análise de variância.

2 Médias seguidas de letras diferentes nas colunas diferem entre si ao nível de 5 웅 de probabilidade, pelo teste de Tukey.

Os produtos captan, mancozeb, tebuconazole CE e triadimenol foram os mais tóxicos na concentração de 10 ppm, resultados esses evidenciados pela elevada inibição da germinação apresentada pelos uredósporos submetidos a esses tratamentos; já os produtos cartap, cyproconazole e propiconazole não diferiram da testemunha.

Na concentração de 100 ppm, os defensivos bitertanol, cartap e cyproconazole foram os menos eficientes em inibir 
a germinação de uredósporos do fungo, quando comparados aos demais produtos que apresentaram desempenho semelhante.

Analisando-se a $E D_{50}$ (Tabela 02 e curvas de regressões representadas nos Apêndices $2 \mathrm{a}$ e $2 \mathrm{~b}$ ), os produtos captan, flutriafol, mancozeb, tebuconazole (CE) e triadimenol figuram entre os melhores, ao contrário do bitertanol, cartap e propiconazole que apresentaram os maiores valores desse parâmetro, necessitando portanto maior concentração do produto para inibir 50\% da germinação de uredósporos.

Este tipo de análise da eficiência de defensivos agrícolas in vitro é muito útil quando realizada conjuntamente com testes in vivo, visando a seleção de produtos. A comparação das análises in vitro $e$ in vivo oferece uma maior confiabilidade nos resultados obtidos. Geralmente, o parâmetro analisado in vitro é a inibição do crescimento micelial dos fungos na presença do produto químico, pois este pode atuar tanto na germinação como no desenvolvimento micelial do fungo. O teste de germinação de esporos, utilizado no presente ensaio, é uma alternativa quando se trabalha com parasitas obrigados, sendo que neste caso há a necessidade do conhecimento do modo de ação do produto, verificando se o mesmo exerce efeito sobre a germinação. Caso contrário, não se justificaria a utilização deste tipo de teste.

A análise da eficiência de fungicidas triazóis sobre a germinação pode originar resultados diversos. Esses fungicidas inibidores da biossíntese do ergosterol são conhecidos por muitos autores como fracos inibidores da germinação (SIEGEL, 1981), embora tubos germinativos de esporos tratados se mostrem freqüentemente menores, inchados ou deformados. De acordo com TRINCI \& RYLEY (1983) esses fungicidas podem afetar a germinação dos esporos de 
algumas espécies de fungos. Segundo PONTZEN \& SCHEINPFLUG (1989), o teste de germinação de esporos é adequado para determinar a eficácia de fungicidas triazóis quando o patógeno inicia a síntese do esterol logo após a germinação, sendo que neste caso a sintese pode ser fortemente inibida, conforme verificaram os autores testando os produtos tebuconazole e bitertanol em Botrytis cinerea e Venturia inaequalis. No caso de fungos que utilizam, para a germinação, reservas de esteróis do próprio esporo, iniciando a sintese somente quando a elongação do tubo germinativo estiver quase completa, o teste não pode ser usado, como é o caso de Puccinia graminis f. sp. tritici.

os resultados observados revelaram o efeito inibitório dos triazóis sobre a germinação de uredósporos de T. discolor. Captan e mancozeb foram altamente eficientes em inibir a germinação dos uredósporos do fungo. De uma maneira geral, produtos protetores exercem efeito inibidor sobre a germinação de esporos (LEROUX, 1981) pois atuam na produção de energia (respiração) e/ou nos processos biossintéticos. Em menor escala, esses produtos interferem na permeabilidade da membrana (BRAGA, 1993). O mancozeb, na concentração de 1 ppm, inibiu a germinação em 96\%, à semelhança dos dados de MICHAILIDES \& OGAWA (1986) que obtiveram 97\% de inibição da germinação de uredósporos de T. discolor de ameixeira, com o produto na concentração de $5 \mathrm{ppm}$. Os resultados obtidos para os produtos na concentração de $1 \mathrm{ppm}$ não forneceram subsídios para verificação da eficiência dos mesmos. Em alguns casos, observou-se uma ação tônica destes produtos em relação à testemunha. Os resultados de $1 \mathrm{ppm}$ foram utilizados apenas para cálculo da $E D_{50}$ (Apêndices $2 \mathrm{a}$ e $2 \mathrm{~b}$ ). 
A menor eficiência do tebuconazole PM em relação ao tebuconazole $C E$ pode ser atribuída ao fato do produto na formulação concentrado emulsionável apresentar maior capacidade de penetração nas células do fungo (KIMATI ${ }^{4}$ ).

A ação fungicida do inseticida cartap foi apenas recentemente descoberta por ITO (1993), para o patossistema Uromyces appendiculatus $X$ feijoeiro, sendo que o modo de ação desse inseticida sobre os fungos ainda é uma incógnita. Apesar desse produto ter apresentado uma alta $E D_{50}$, exerceu um certo efeito inibitório sobre a germinação (Tabela 02).

\subsubsection{Eficiência de defensivos agrícolas no controle da ferrugem em plantas adultas de pessegueiro}

Os resultados da eficiência de defensivos agrícolas no controle da ferrugem, em plantas adultas de pessegueiro, estão representados nas Figuras 08, 09, 10 e 11 .

Comparando-se as curvas de progresso da doença no. tratamento testemunha dos cultivares Flor da Prince e Aurora II (Figura 08), observa-se a semelhança na forma dessas curvas. No cultivar Aurora II, foram observadas maiores inóculo inicial $\left(x_{0}\right)$ e porcentagem de severidade da doença.

As retas de regressões das curvas de progresso da doença foram comparadas pelo teste $t$, conforme recomendado por TENG (1981), sendo que diferenças significativas foram observadas apenas na quantidade de inóculo inicial ( $\mathrm{x}_{0}=30.2$ para Aurora e $\mathrm{x}_{0}=33.2$ para Flor da Prince); as taxas aparentes de infecção não diferiram entre si (-4.02 para Aurora e -4.46 para Flor da Prince). Foram obtidas taxas 
aparentes de infeç̧ão de 0.074 e 0.087/dia para os cultivares Aurora II e Flor da Prince, respectivamente. Estes valores são comparáveis às taxas de infecção da ferrugem do feijoeiro ( 0.08 a $0.1 /$ dia) nos cultivares mais suscetíveis como Rosinha (MENDES \& BERGAMIN FILHO, 1990) e Mỉlionário (CARMO et alii, 1994), e aproximadamente dez vezes maiores que as taxas de cultivares moderadamente resistentes como Carioca (MENDES \& BERGAMIN FILHO, 1990). Esta elevada taxa aparente de infecção justifica o rápido crescimento da doença no tempo, mesmo com um período latente relativamente mais longo do que $\circ$ apresentado em outros patossistemas.

Os maiores indices de severidade, do tratamento testemunha (Figura 08), e a maior desfolha (Figura 11), observados no cultivar Aurora II, são decorrentes da defasagem em quinze dias na instalação desse experimento em relação ao cultivar Flor da Prince. No final do mês de janeiro, as condições climáticas foram muito favoráveis à doença (Apêndice 03). Além dos altos índices pluviométricos registrados, as temperaturas mínima e média foram, respectivamente, 18 e $23^{\circ} \mathrm{C}$, coincidentemente as mesmas testadas em casa-de-vegetação e consideradas ótimas para 0 desenvolvimento da doença. A temperatura máxima do mês, de $28^{\circ} \mathrm{C}$, ficou abaixo do limite superior para a germinação dos uredósporos. Essas condições climáticas favoráveis à doença ocorreram aproximadamente duas semanas antes da última avaliação, período esse próximo ao período latente de 17 a 19 dias obtido anteriormente.

Através da Figura 09 pode ser observado que na primeira avaliação da severidade da ferrugem, em plantas do cultivar Flor da Prince, as parcelas experimentais estavam bem uniformes, não apresentando diferenças estatísticas 
significativas entre si. Na última avaliação, os produtos tebuconazole PM, mancozeb, captan e cyproconazole apresentaram eficiência superior aos demais; os produtos propiconazole e bitertanol não diferiram da testemunha. Tanto na primeira como na última avaliação não foram detectadas diferenças entre a face da planta amostrada e os respectivos tratamentos, comprovando que a posição do quadrante não exerceu qualquer tipo de influência sobre a severidade da doença.

No que se refere ao parâmetro desfolha (Figura 09), os tratamentos apresentaram comportamento semelhante por ocasião da última avaliação (18/01/1994). No entanto, 15 dias mais tarde, a diferença entre os tratamentos tornaramse mais visiveis. A Figura 10 mostra a acentuada diferença na porcentagem de desfolha da testemunha em relação aos melhores tratamentos. Essa diferença é resultado da ocorrência de condições climáticas muito propicias (Apêndice 03).

Para o cultivar Aurora II, nota-se na Figura 11 uma grande homogeneidade das parcelas na primeira avaliação, não ocorrendo diferenças estatísticas significativas entre os tratamentos. $\mathrm{Na}$ última avaliação, os defensivos agrícolas mancozeb, tebuconazole ( $\mathrm{CE}$ e PM), captan e cartap se destacaram. A posição intermediária ocupada pela testemunha em relação aos demais tratamentos, é resultado do alto número de folhas jovens, com baixa porcentagem de severidade. A alta porcentagem de desfolha na testemunha (Figura 11) justifica a emissão de novas brotações. Diferenças entre os tratamentos e o quadrante amostrado também não foram observadas. 

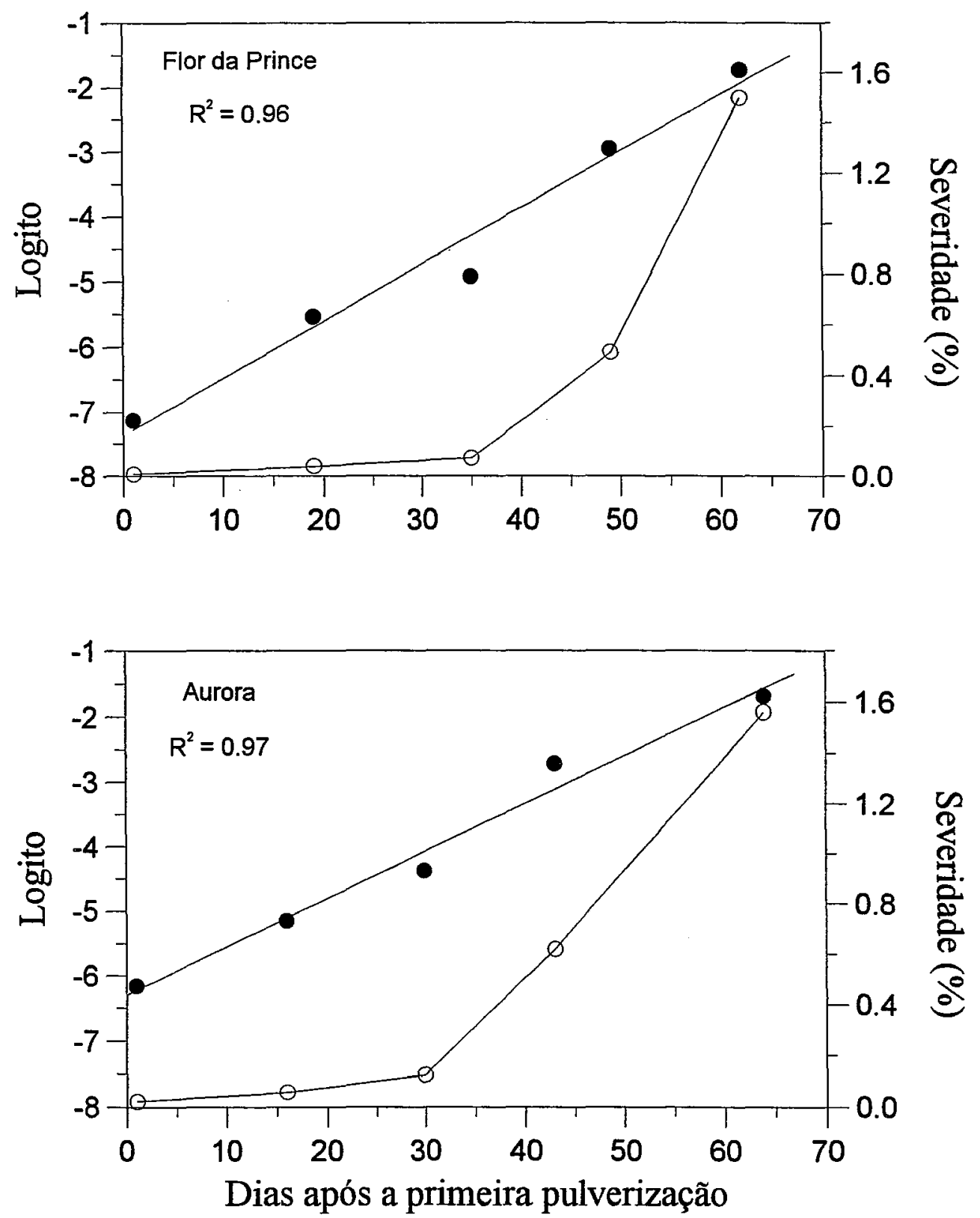

Figura 08. Curvas de progresso da doença no tratamento testemunha dos cultivares Flor da Prince e Aurora II.

$\mathrm{R}^{2}=$ coeficiente de determinação da reta 

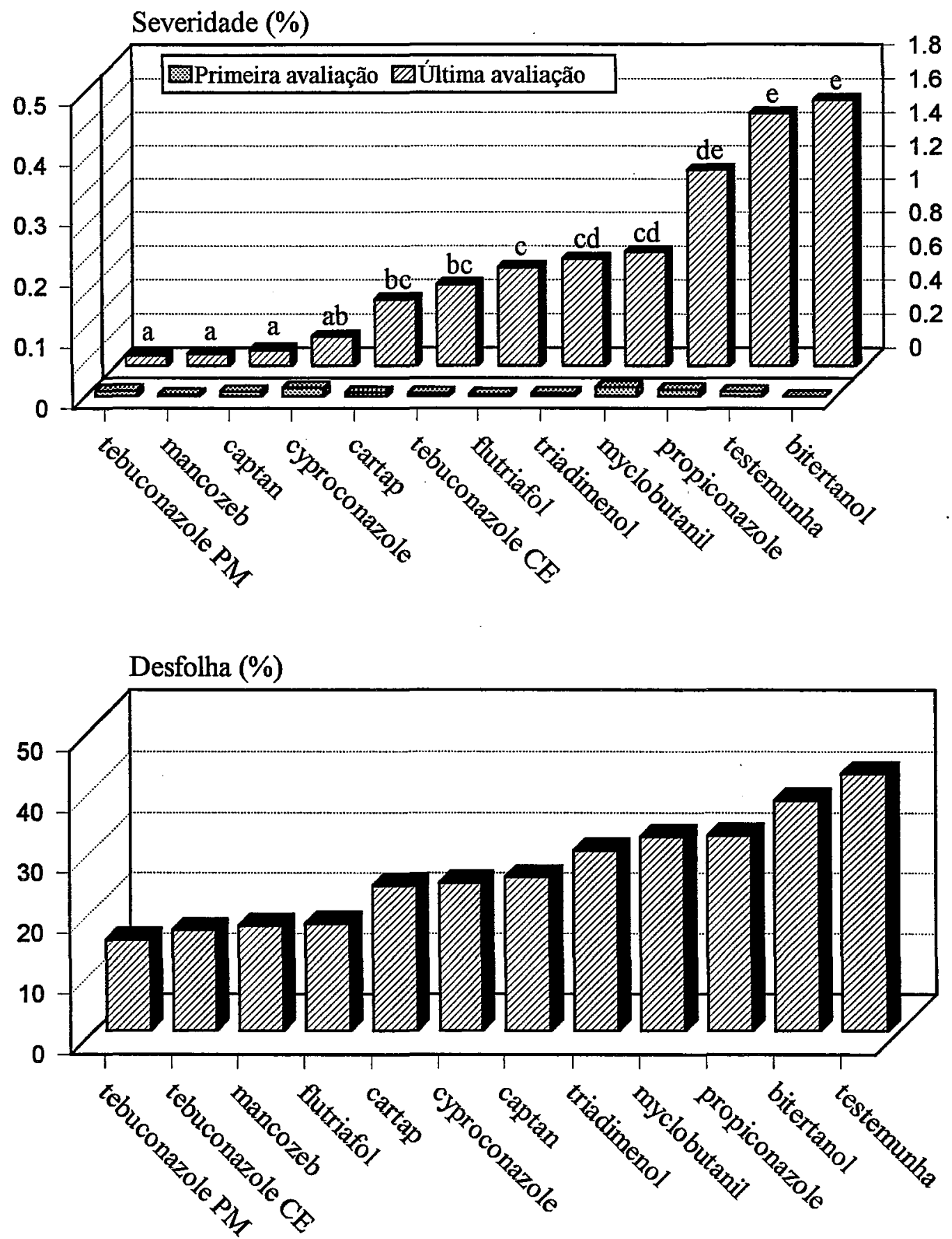

Figura 09. Efeito dos defensivos agrícolas na severidade da ferrugem e na desfolha do cultivar Flor da Prince.

Médias com letras distintas diferem entre si ao nível de 5\% de probabilidade pelo teste de Tukey. 

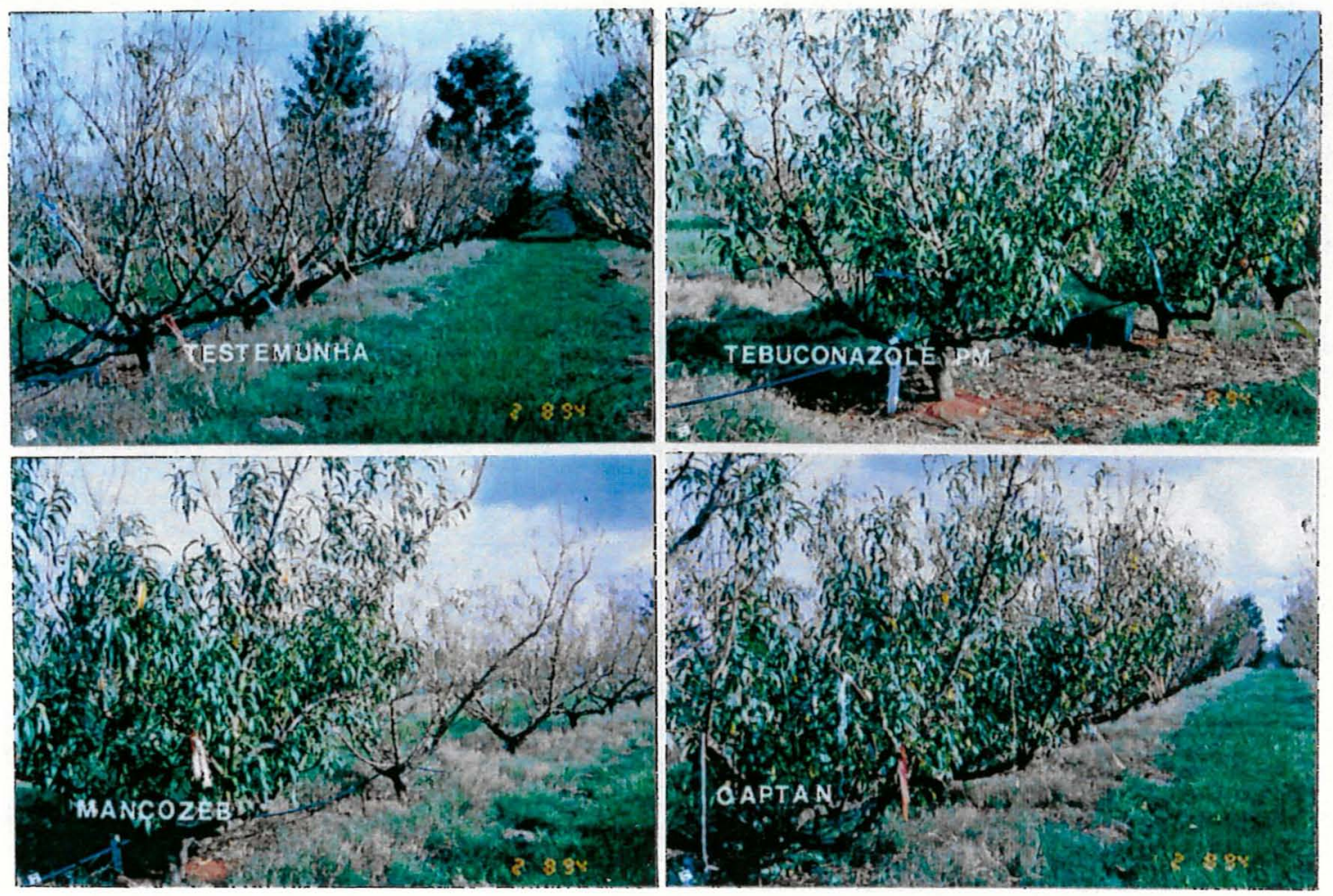

Figura 10. Vista parcial do cultivar Flor da Prince

Examinando-se a porcentagem de desfolha ocorrida nesse cultivar (Figura 11) constata-se a superioridade dos produtos mancozeb, captan e tebuconazole ( $P M$ e $C E$ ), que permitiram uma maior retenção de folhas na planta.

Os resultados obtidos reproduzem o que foi observado in vitro. Os produtos mancozeb, captan e tebuconazole foram os mais eficientes no controle da ferrugem. In vitro, o tebuconazole PM apresentou uma eficiência inferior ao tebuconazole CE, fato já explicado no item anterior; no campo, a superioridade da formulação pó molhável pode ter ocorrido devido à adição de um espalhante adesivo, que permitiu uma melhor cobertura do produto sobre as plantas (a formulação concentrado emulsionável já contém uma certa 
quantidade de espalhante adesivo, porém em menor quantidade). Outra hipótese é a maior dose do produto pó molhável utilizada (75 g/100 l) em relação ao concentrado emulsionável $(0.5 \mathrm{l} / \mathrm{ha})$.

os produtos protetores captan e mancozeb, recomendados por vários autores para controle dessa doença (BLEICHER \& TANAKA, 1982; PENTEADO, 1983; KABLE et alii, 1987b e TEVIOTDALE et alii, 1994), foram altamente eficientes nos dois experimentos, resultados divergentes dos obtidos por produtores de pêssego da região de Paranapanema-SP. Essa diferença na eficiência foi atribuída à tecnologia inadequada de aplicação dos produtos pelos agricultores. Em ambos os ensaios, a pulverização foi realizada com um pulverizador costal motorizado, que forneceu perfeita cobertura dos produtos sobre as folhas. os produtores fazem as aplicações com trator, utilizando o bico original do pulverizador Berthould. Recentemente, testes de distribuição de gotas sobre tiras de papel sensivel, colocadas à várias alturas da árvore, mostraram má distribuição do produto, com excesso de cobertura no terço inferior da planta e ausência no terço superior. A utilização desse tipo de bico causa uma distribuição irregular das gotas com consequiente cobertura desuniforme.

A baixa eficiência dos produtos bitertanol e propiconazole foram observadas tanto in vitro como in vivo, concordando com KABLE et alii (1987b) que verificaram uma menor eficiência do bitertanol em relação aos ditiocarbamatos mancozeb e zineb e a ineficiência do propiconazole como protetor. Segundo estes autores (1987a) o propiconazole e o myclobutanil apresentaram efeito na forma curativa, o que não foi observado neste experimento. 

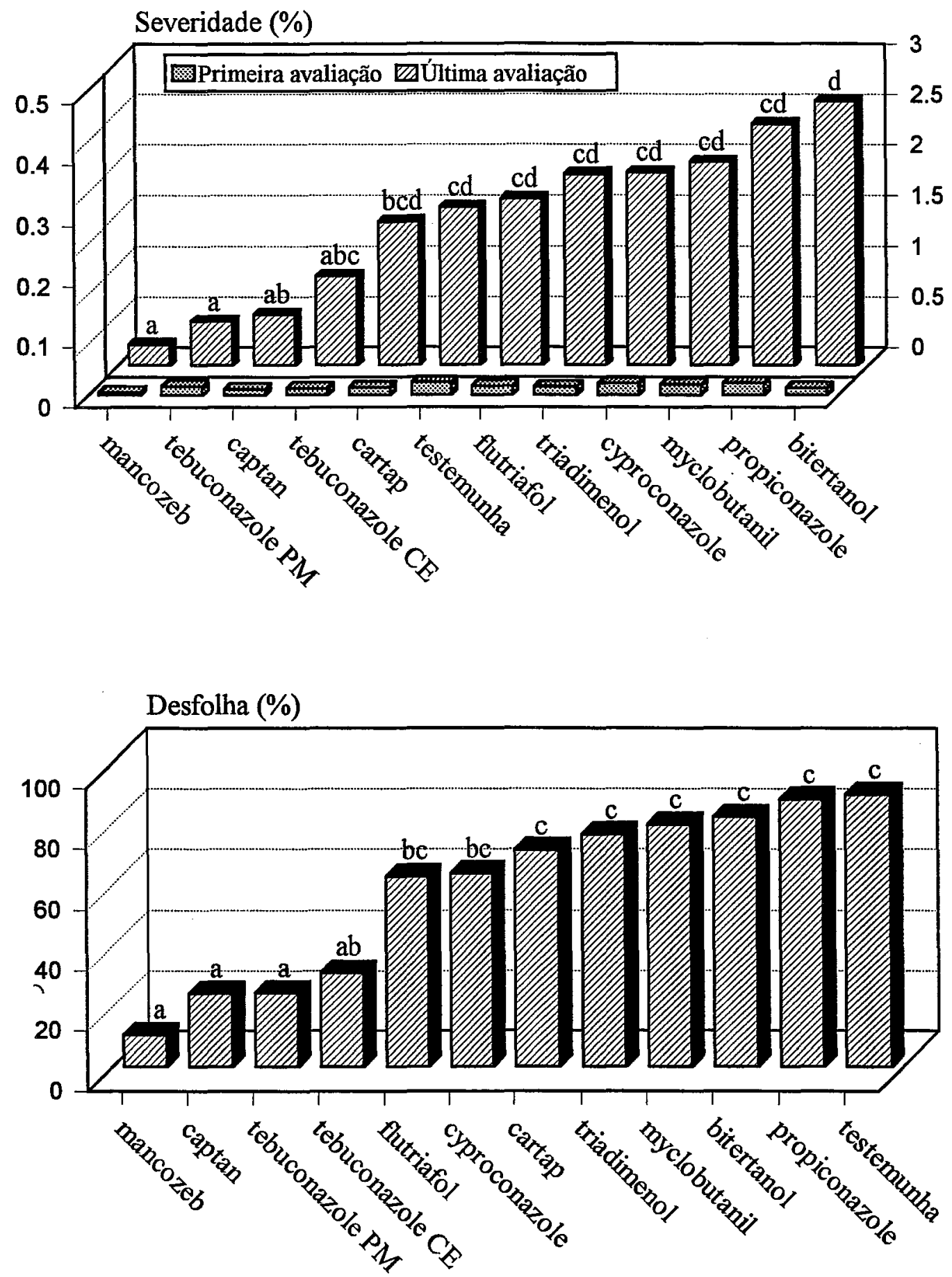

Figura 11. Efeito dos defensivos agrícolas na severidade da ferrugem e na desfolha do cultivar Aurora II. Médias com letras distintas diferem entre si ao nível de 5\% de probabilidade pelo teste de Tukey. 
o cartap apresentou uma eficiência moderada em ambos os cultivares. No campo, foram notadas pústulas brancas após a aplicação do inseticida, embora novas pústulas marrons fossem formadas em curto espaço de tempo, devido ao baixo poder residual deste produto. A combinação deste produto com fungicidas e/ou a diminuição no intervalo de aplicação podem ser alternativas de manejo que podem trazer resultados satisfatórios.

De uma maneira geral, os resultados obtidos referemse a um "screening" preliminar da eficiência de alguns defensivos, sendo que para a elaboração de um sistema de manejo adequado, muitos estudos são necessários, como por exemplo o tipo e dosagem econômica do produto a ser empregado, o intervalo e época de aplicação, a permanência de resíduos nos frutos, entre outros.

\subsubsection{Efeito protetor, curativo e erradicante do inseticida cartap na ferrugem do pessegueiro}

Os resultados do efeito protetor, curativo e erradicante do inseticida cartap na ferrugem do pessegueiro estão apresentados nas Figuras 12 e 13 e na Tabela 03.

Analisando-se as curvas de progresso da doença de plantas onde o cartap foi aplicado de forma curativa, observa-se uma menor freqüência de infecção e um maior período latente, comparados com os valores apresentados no tratamento testemunha (Figura 12).

o tratamento protetor mostrou eficiência máxima, uma vez que não houve nenhuma formação de pústulas nas folhas (Figura 13c). No tratamento curativo, foram observadas, no início da avaliação, lesões coriáceas deprimidas, 

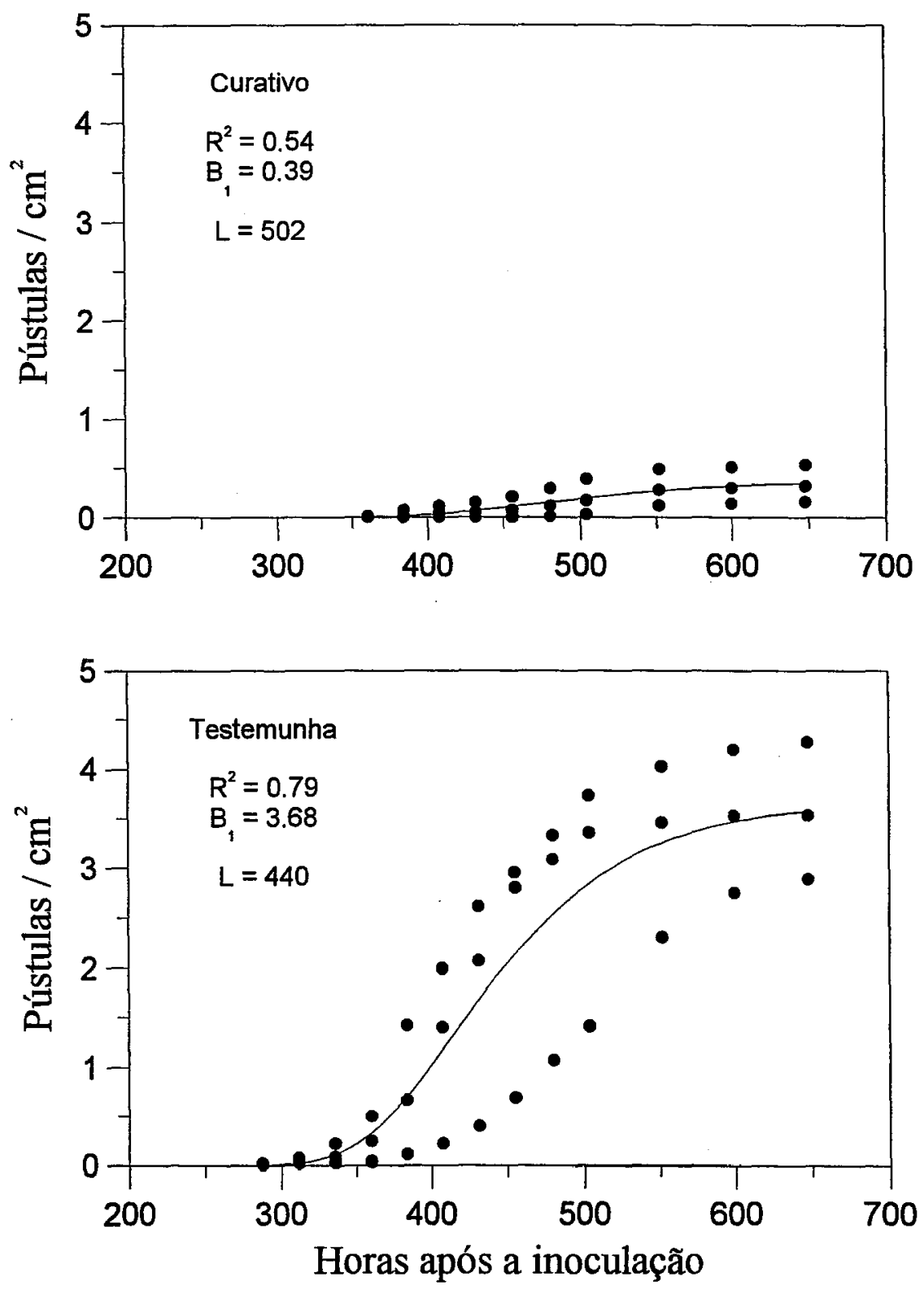

Figura 12. Curvas de progresso da ferrugem do pessegueiro em mudas pulverizadas com o inseticida cartap 24 horas após a inoculação (curativo) e em mudas não tratadas (testemunhá).
$\mathrm{R}^{2}=$ coeficiente de determinação do ajuste
$\mathrm{B}=$ assíntota máxima (pústulas $/ \mathrm{cm}^{2}$ )
$L^{1}=$ periodo latente (horas) 
provavelmente no local de deposição do inóculo sobre a folha, inóculo esse que teve seu desenvolvimento parcialmente paralisado pelo inseticida (Figura 13d). Pequeno número de pústulas marrons formou-se no decorrer das avaliações (Figura 12): O cartap aplicado na forma erradicante tornou 75\% das pústulas maduras esbranquiçadas, após três dias da aplicação do produto. Os resultados dessa forma de aplicação foram menos notáveis que aqueles observados em feijoeiro (ITO, 1993) onde 100\% de pústulas mostraram-se completamente brancas. No presente estudo, além de não agir sobre a totalidade das pústulas, a mudança de coloração foi menos evidente dificultando a avaliação do ensaio (Figura 13b).
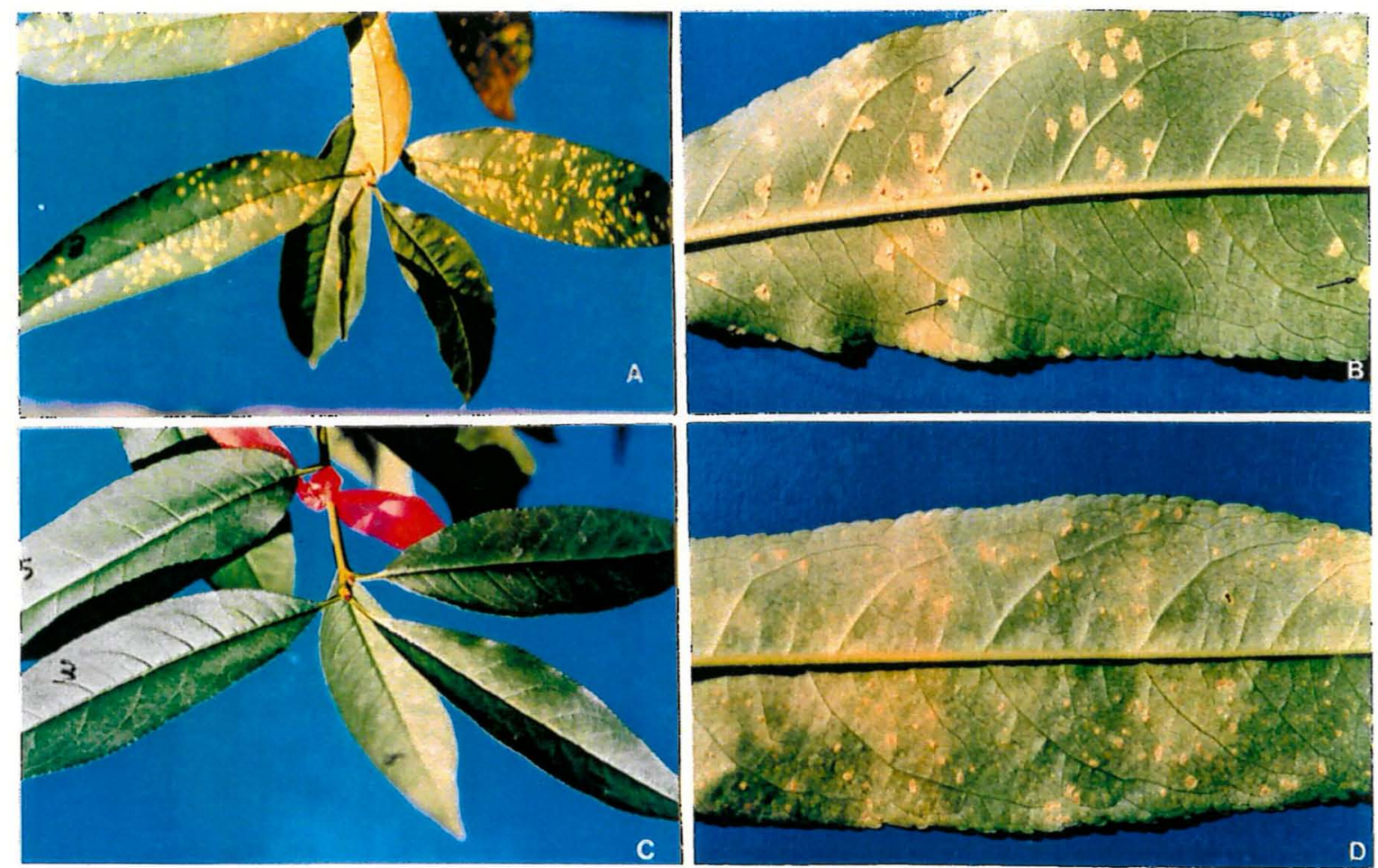

Figura 13.

diferentes tratamentos com o inseticida cartap na ferrugem do pessegueiro. $A=$ testemunha, $B=$ cartap erradicante, $\quad C=$ cartap protetor e $\mathrm{D}=$ cartap curativo 
Quanto à germinação de uredósporos retirados de plantas submetidas aos diversos tratamentos, pode-se constatar, através da Tabela 03, a eficiência do cartap na forma erradicante. O cartap aplicado na forma curativa, embora com efeito inferior ao erradicante, foi superior à testemunha.

Tabela 03. Germinação ( $\left.\frac{\circ}{0}\right)$ de uredósporos de T. discolor retirados de plantas submetidas aos diferentes tratamentos com o inseticida cartap.

\begin{tabular}{cc}
\hline Tratamentos & Germinação (8) \\
\hline erradicante & $34.60 \mathrm{a}^{1}$ \\
curativo & $53.00 \mathrm{~b}$ \\
testemunha & $72.20 \mathrm{C}$ \\
\hline
\end{tabular}

C.V. $\frac{8}{8}=4.1$

${ }^{1}$ Médias seguidas de letras diferentes diferem entre si ao nível de $5 \%$ de probabilidade pelo teste de Tukey.

Os dados obtidos indicam o potencial de controle desse inseticida na ferrugem do pessegueiro.

o cartap na forma protetora impediu completamente o desenvolvimento da doença (Figura 13c), concordando com ITO (1993) que obteve 99\% de inibição na formação de pústulas de Uromyces appendiculatus do feijoeiro, quando da aplicação preventiva do produto $(24$ horas antes da inoculação) .

A redução na freqüência de infecção e o aumento do período latente, no tratamento curativo, mostram que a interferência do produto, no ciclo das relações patógenohospedeiro-ambiente, deve ter ocorrido na infecção e/ou colonização. A maioria dos esporos já havia germinado 24 horas após a inoculação, época de aplicação do inseticida. 
Segundo ELLISON et alii (1990), índices de germinação igual ou superior a $80 \%$ são obtidos dentro de uma hora e meia de incubação nas temperaturas de 13 a $26^{\circ} \mathrm{C}$.

os dados obtidos levam a supor que $\mathrm{O}$ inseticida interfere na fisiologia do fungo. A menor porcentagem de germinação de uredósporos, coletados em plantas que receberam o produto na forma curativa, reforça este fato. 


\section{CONCLUSÕES}

1) A faixa de temperatura estimada de 10 a $22^{\circ} \mathrm{C}$ foi a ótima para a germinação de uredósporos de $T$. discolor, sendo explicada pela função Beta generalizada.

2) A temperatura de $18^{\circ} \mathrm{C}$ favoreceu a infecção e a de $23^{\circ} \mathrm{C}$ a colonização.

3) Os produtos captan, mancozeb e tebuconazole nas formulações $\mathrm{CE}$ e $\mathrm{PM}$ foram eficientes no controle da ferrugem do pessegueiro. Os produtos bitertanol e propiconazole foram ineficientes.

4) O inseticida cartap apresentou potencial de controle da ferrugem do pessegueiro, quando pulverizado de forma preventiva, curativa e erradicante. 


\section{REFERÊNCIAS BIBLIOGRÁFICAS}

ANDERSON, H.W. Diseases of fruit crops. New York, MC Graw Hill, 1956. $501 \mathrm{p}$.

BACCHI, L.M.A. Quantificação de parâmetros monocíclicos relacionada a epidemias no sistema Uromyces appendiculatus - feijoeiro. Piracicaba, 1993. 99p. (Doutorado - Escola Superior de Agricultura "Luiz de Queiroz"/USP).

BARBOSA, W.; CAMPO-DALL'ORTO, F.A.; OJIMA, M.; SAMPAIO, V.R.; BANDEL, G. Ecofisiologia do desenvolvimento vegetativo e reprodutivo do pessegueiro em região subtropical. Campinas, Instituto Agronômico de Campinas, 1990. 37 p. (Documentos IAC, 17).

BRAGA, J.R. Fungicidas ditiocarbamatos no controle de doenças de plantas. Revisão Anual de Patologia de Plantas, Passo Fundo, 1: 349-68, 1993.

BLEICHER, J. \& TANAKA, H. Doenças do pessegueiro no Estado de Santa Catarina. 2. ed. Florianópolis, Empresa Catarinense de Pesquisa Agropecuária S.A., 1982. 53 p. 
BOLKAN, H.A.; OGAWA, J.M.; MICHAILIDES, T.J.; KABLE, P.F. Physiological specialization in Tranzschelia discolor. Plant Disease, St. Paul, 69(6): 485-6, 1985.

CARTER, M.V.; MOLLER, W.J.; PADY, S.M. Factors affecting uredospore production and dispersal in Tranzschelia discolor. Australian Journal of Agricultural Research, East Melbourne, 21: 905-14, Nov.1970.

CARMO, M.G.F.; MAFFIA, L.A.; HALLER, M.C.P.; ARAUJO, G.A.A. Progresso e disseminação da ferrugem do feijoeiro nos sistemas de monocultivo e de consórcio com o milho. Fitopatologia Brasileira, Brasilia, $19(3):$ 413-9, set. 1994.

CUMMINS, G.B. \& HIRATSUKA, Y. Ilustrated genera of rust fungi. Minnesota, American Phytopathology Society, 1983. $152 \mathrm{p}$.

CUNNINGHAM, G.H. Leaf - rust, Puccinia pruni-spinosae Pers. Its appearance, cause, and control. New Zealand Journal of Agriculture, Wellington, 25: 271-7, Nov. 1922 .

DIXON, W.J. BMDP statistical Software. University of California Press, Berkeley, 1985.

DUNEGAN, J.C. The rust of stone fruits. Phytopathology, St. Paul, 28(6):411-27, June 1938. 
DUNEGAN, J.C. \& SMITH, C.O. Germination experiments with uredio-and teliospores of Tranzschelia pruni-spinosae discolor. Phytopathology, st. Paul; 31:189-91, Feb.1941.

EISENSMITH, S.P. PlotIt Graphics and Statistics. ICS, Frankfurt, 1985.

ELLISON, P.J.; CULLIS, B.R.; KABLE, P.F. The effect of light and temperature on in vitro germination and germ tube growth of urediniospores of Tranzschelia discolor. Australian Journal of Agricultural Research, East Melbourne, 43(3): 451-64, 1992.

ELLISON, P.J.; MCFADYEN, L.; KABLE, P.F. Overwintering of Tranzschelia discolor in prune orchards in New South Wales. Australian Journal of Agricultural Research, East Melbourne, 38: 895-905, 1987.

ELLISON, P.J.; CULLIS, B.R.; BAMBACH, R.W.; KABLE， P.F. The effect of temperature on in vitro germination and germ tube growth of urediniospores of Tranzschelia discolor. Australian Journal of Agriculture Research, East Melbourne, 41(3): 479-88, 1990.

ELLISON, P.J.; MCFADYEN, L.M.; CULLIS, B.R.; KABLE， P.F. Survival of dispersed urediniospores of Tranzschelia discolor Fckl. (Tranz. \& Litv.) on leaves of Prunus domestica L. CV. 'Agen' in spring and summer in the Murrumbidge irrigation areas. Australian Journal of 
Agricultural Research, East Melbourne, 39: 847-56, 1988 .

EMPRESA BRASILEIRA DE PESQUISA AGROPECUARIA. Cartilha do produtor de pêssego. Pelotas, 1990. $30 \mathrm{p}$.

FREITAS, J.C.; GIGLIOTI, E.A.; KIMATI, H. Novos produtos para o controle químico da ferrugem branca do crisântemo (Dendrathema morifolium (Ramat) Tzvelev). IN: CONGRESSO PAULISTA DE FITOPATOLOGIA, 17, Araras, 1994. (Resumo). Summa Phytopathologica, Jaguariuna, 20(1):46, jan./mar. 1994.

GOLDSWORTHY, M.C. \& SMITH, R.E. Studies on a rust of clingstone peaches in California. Phytopathology, st. Paul, 21 (2):133-68, Feb.1931.

HAU, B. \& KRANZ, J. Mathematics and statistics for analysis in epidemiology. In: KRANZ, J. Epidemics of Plant Diseases. 2.ed. Berlin, Springer-Verlag, 1990. cap.2, p.12-52.

HORSFALL, J.C. \& BARRAT, R.W. An improved grading system for measuring plant diseases. Phytopathology, st. Paul, 35:655, 1945 .

HUTTON, K.E. Rust of stone fruits trees. Agricultural Gazzette of New South Wales, Sydeney, 63(3): 135-8, 1950. Apud Review of Applied Mycology, Surrey, 29:515, 1950. (Resumo). 
ITO, M.F. Ação fungicida do inseticida cartap sobre a ferrugem do feijoeiro. Piracicaba, 1993. 65p. (Doutorado - Escola Superior de Agricultura "Luiz de Queiroz"/USP).

JAMES, W.C. Assessment of plant diseases and losses. Annual Review of Phytopathology, Palo Alto, 12: 27-48, 1974.

KABLE, P.F.; ELLISON, P.J.; BAMBACH, R.W. Physiologic specialization of Tranzschelia discolor in Australia. Plant Disease, St. Paul, 70(3): 202-4, 1986.

KABLE, P.F.; KEEN, B.J.; BAMBACH, R.W. Evaluation of - fungicides for curative activity against Tranzschelia discolor, cause of the rust disease of French prune (Prunus domestica L.). Australian Journal of Agriculture Research, East Melbourne, 38(3): 577-85, $1987 a$.

KABLE, P.F.; BAMBACH, R.W; ELLISON, P.J.; WATSON, A.; KALDOR, C.J. Fungicidal control of rust of french prune caused by Tranzschelia discolor. Australian Journal of Agriculture Research, East Melbourne, 38(3): $565-76,1987 \mathrm{~b}$.

LEROUX, P. Les modes d'action des substances antifongiques à usages agricoles. La Défense des Végétaux, 207: 5984, Février 1981. 
MEHTA, Y.R. \& ZADOKS, C. Uredospore production and sporulation period of Puccinia recondita f. $\mathrm{sp}$. triticina on primary leaves of wheat. Netherland Journal Plant Pathology, 76: 267-76, 1970.

MENDES, B.M.J. \& BERGAMIN FILHO, A. A análise da curva de progresso da ferrugem do feijoeiro (Uromyces phaseoli var. typical em condiões naturais de infecção. Fitopatologia Brasileira, Brasília, 15(4): 314-7, Dez.1990.

MICHAILIDES, T.J. \& OGAWA, J.M. Chemical control of prune leaf rust. Plant Disease, St. Paul, 70(4): 307-9, Apr. 1986.

MINZON, D.B. Pêssegos em destaque. Casa da Agricultura, Campinas, 44: 18-22, jul./ago.1982.

MITCHELL, D.T. Some effects of temperature on the viability of peach rust uredospores. Phytophylactica, Pretoria, 7(3): 117, Sept.1975.

PARLEVLIET, J.E. Components of resistance that reduce the rate of epidemic development. Annual Review of Phytopathology, Palo Alto, 17: 203-22, 1979.

PENTEADO, S.R. Os inimigos da cultura do pêssego. Correio Agrícola, São Paulo, 1: 488-96, 1983.

PONTZEN, R. \& SCHEINPFLUG, H. Effects of triazole fungicides on sterol biosynthesis during germination of 
Botrytis cinerea, Venturia inaequalis and Puccinia graminis f. 'sp. tritici. Netherland Journal of Plant Pathology, 95(1): 151-61, 1989.

SIEGEL, M.R. Sterol inhibiting fungicides: effects on sterol biosynthesis and sites of action. Plant Disease, St. Paul, 65(12): 986-9, 1981.

SMITH, C.O. A study of Tranzschelia pruni-spinosae on prunus species in California. Hilgardia, California, $17(7)$ : 251-66, Mar.1947.

TENG, P.S. Validation of computer models of plant disease epidemics. A review of philosophy and methodology. Journal of Plant Diseases and Protection, Stuttgart, $88(1)$ : 49-63. 1981 .

TEVIOTDALE， B.I.; HARPER， D.M.; MICHAILIDES， T.J.; SIBBETT, G.S. Lack of effect of stone fruit rust on yield of french prune trees and survival of urediniospores of the pathogen on leaves, shoots, and buds. Plant Disease, St. Paul, 78(2): 141-5, 1994.

TRINCI, A.P.J. \& RYLEY, J.F. Biochemical and cellular aspects of the antifungal action of ergosterol biosynthesis inhibitors. In: SYMPOSIUM OF THE BRITISH MYCOLOGICAL SOCIETY, 9., Manchester, 1983. Mode of action of antifungal agents. Cambridge, Cambridge University Press, 1983. p.257-82. 


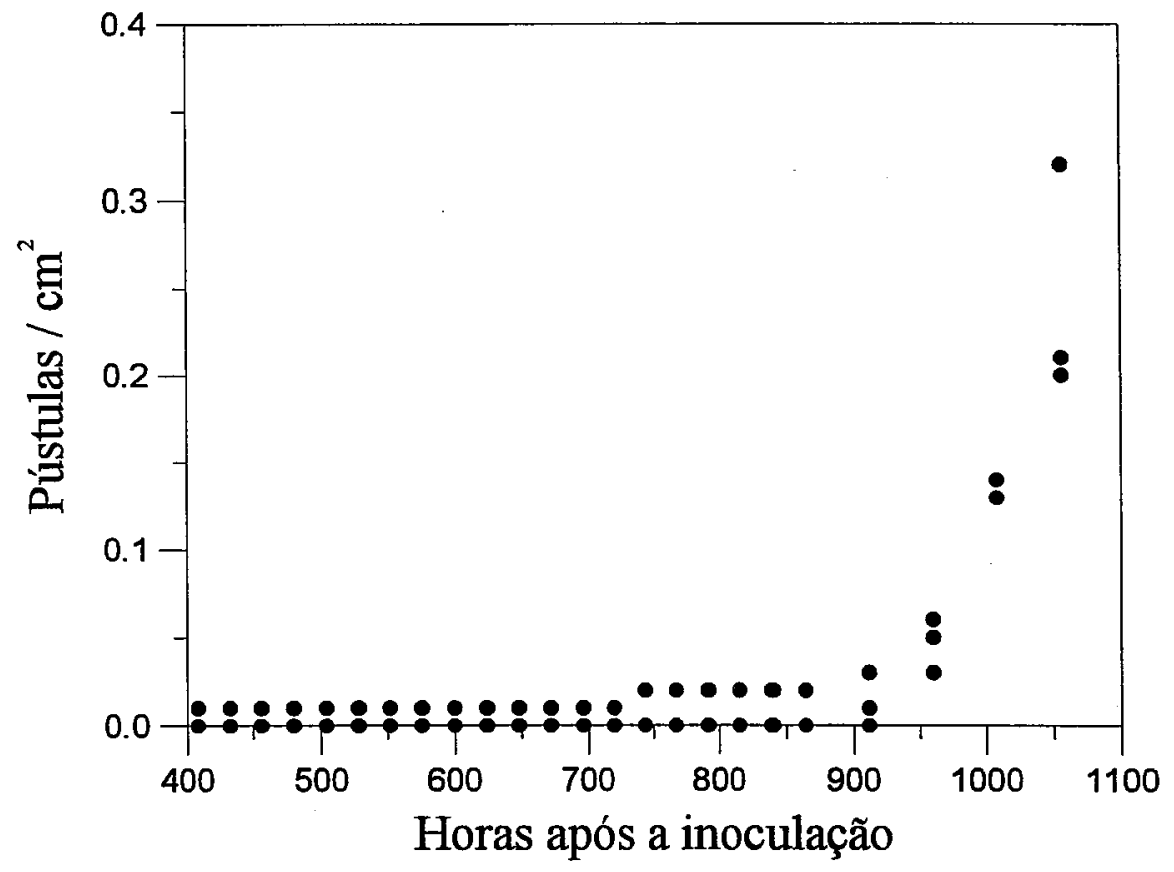

Apêndice 01. Curva de progresso da ferrugem do pessegueiro na temperatura de $8^{\circ} \mathrm{C}$. 


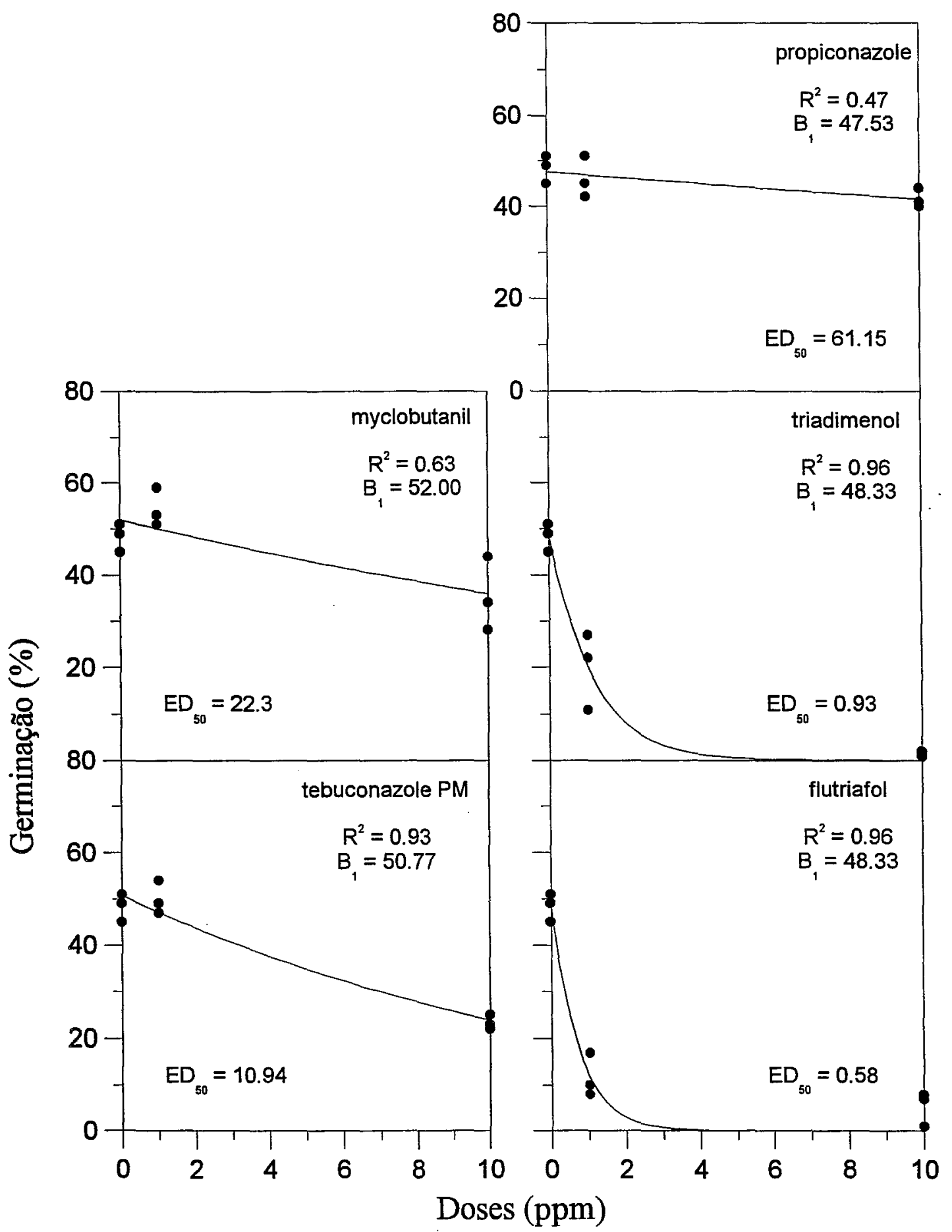

Apêndice 2b. Germinação de uredósporos de T. discolor em meios com defensivos agrícolas (círculos) e ajustes das curvas aos dados observados (1inha).

$\mathrm{R}^{2}=$ coeficiente de determinação do ajuste

$\mathrm{B}_{1}=$ assintota máxima (\% de germinação) 


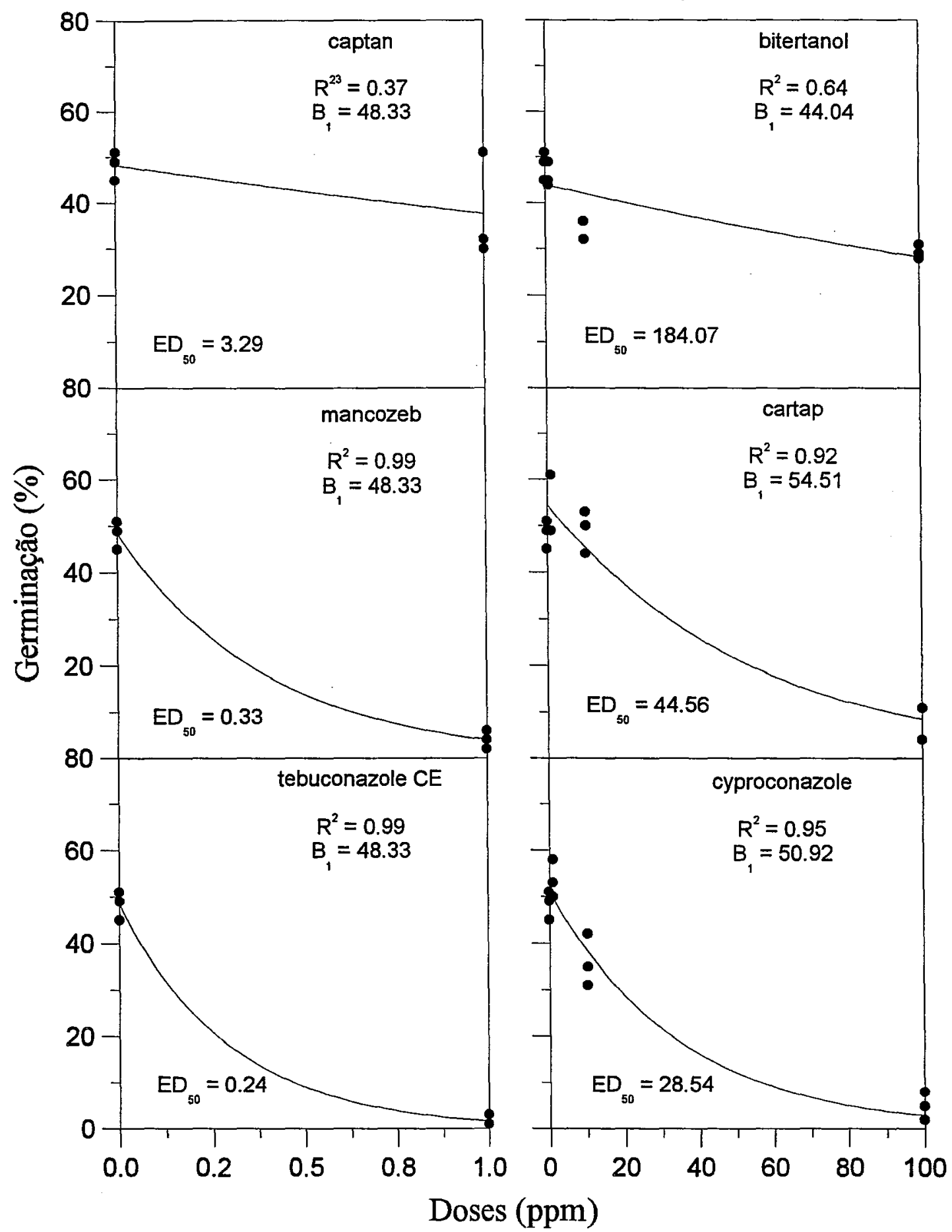

Apêndice 2a. Germinação de uredósporos de T. discolor em meios com defensivos agrícolas (círculos) e ajustes das curvas aos dados observados (linha).

$\mathrm{R}^{2}=$ coeficiente de determinação do ajuste

$\mathrm{B}_{1}=$ assíntota máxima (\% de germinação) 

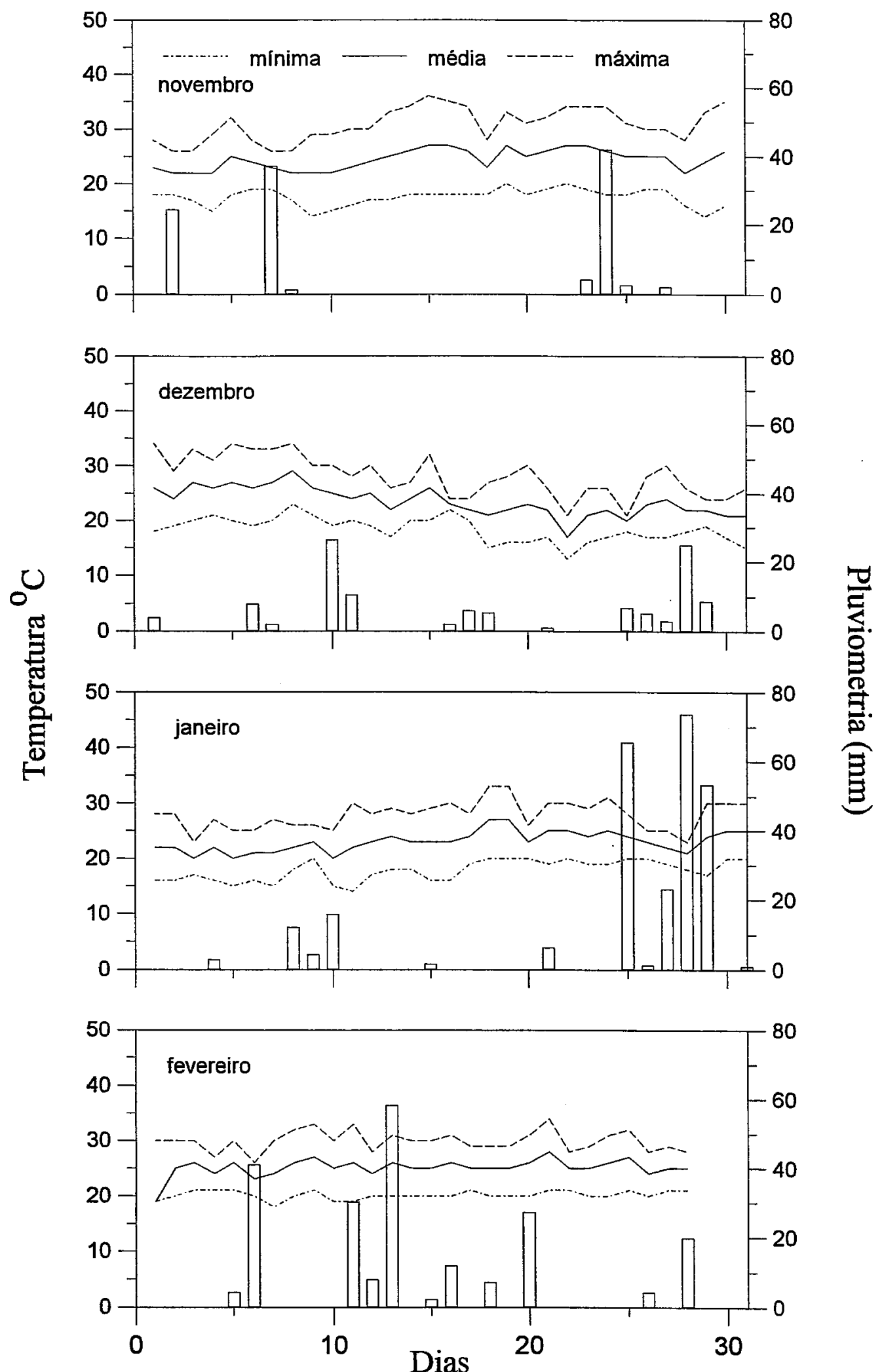

Apêndice 03. Dados climáticos (temperaturas mínima, média e máxima e pluviometria) obtidos na estação meteorológica de Paranapanema. 